\title{
Analisis dan Perancangan Kursi Penumpang Bis Pariwisata Ditinjau dari Aspek Ergonomi di PT. XYZ Bandung
}

\author{
Analysis and Design of Passenger Seats of Tourism B us \\ by Ergonomic Pers pective at PT. XYZ Bandung
}

\author{
Wawan Yudiantyo, Dwi Hartadinata \\ Program Studi Teknik Industri, Univers itas Kristen Maranatha, Bandung \\ E-mail: wawany@yahoo.com,dwi_hartadinata@yahoo.com
}

\begin{abstract}
Abstrak
PT XYZ Bandung adalah salah satu perusahaan yang bergerak dibidang penyediaan jasa transportasi khususnya bis pariwisata, dimana perusahaan tersebut ingin meningkatkan kualitas pelayanannya untuk memenangkan persaingan bisnis. Masalah-masalah yang dihadapi perusahaan antara lain: Desain kursi penumpang bis yang kurang nyaman, fasilitas fisik yang kurang memadai, lingkungan fisik yang masih kurang baik, aspek K3 yang perlu perbaikan, serta tata letak bis yang juga perlu dilakukan perbaikan.

Dari hasil analisis data, diketahui bahwa desain kursi penumpang bis tidak ergonomis karena tidak sesuai dengan ukuran antropometri tubuh yang disarankan. Masalah lainnya, tingkat kebisingan dan tingkat pencahayaan yang perlu dilakukan perbaikan, belum tersedianya prosedur dan peralatan $K 3$, serta tata letak bis yang kurang ergonomis.

Untuk menanggulangi permasalahan di atas, maka dirancang kursi penumpang bis yang lebih ergonomis, fasilitas fisik bis yang ergonomis (sandaran tangan, meja makan, tempat majalah, sabuk pengaman, tempat gelas/botol, sandaran kaki, rel, dan kursi penumpang). Fasilitas fisik dirancang beberapa alternatif, kemudian digunakan metode concept scoring untuk memilih alternatif terbaik. Selain itu diusulkan juga lingkungan fisik yang lebih ergonomis (kebisingan dan pencahayaan), penerapan aspek K3, serta beberapa alternatif tata letak bis baru yang dapat dipergunakan.

Dengan usulan tersebut diharapkan penumpang dapat merasa nyaman saat duduk dan berada di dalam perjalanan karena desain kursi penumpang serta fasilitas fisik yang ergonomis, lingkungan fisik yang lebih memberikan kenyamanan,, penerapan prosedur K3 yang akan meningkatkan kesehatan dan keselamatan bagi penumpang maupun pengemudi, serta beberapa alternatif tata letak baru (ekonomis/realistis dan ergonomis/idealis) yang menjadi pilihan bagi perusahaan untuk digunakan.
\end{abstract}

Kata kunci : Kursi Penumpang Bis, Ergonomis, Antropometri, Concept Scoring, Tata Letak Bis.

\begin{abstract}
PT XYZ Bandung is one of the company engaged in the provision of bus transport services, especially tourism, which wanted to improve its service quality to win the busines sompetition. The problems are: design of passenger seat buses is less comfortable, inadequate physical facilities, the physical environment is still not good, safety and health aspects that need improvement, as well as the layout of the bus which also needs to be improved.

From the analysis of the data, it is known that the design of bus passenger seats is not ergonomic because it does not fit in the recommended anthropometric body. The other problems, noise intensity and lighting intensity need to be improved, there is no safety and health procedures and equipment, and bus layout is not ergonomic.

To improved the problems we designed bus passenger seat by correcting the dimension, we also adding the seat facilities like arm rests, a dining table, a magazine, seat belt, cup holder / bottle, back of legs, and rails. After it we made a few alternatives, and choose the best alternative by concept scoring method. Then we designed ergonomic physical environment (noise and lighting), safety and health procedures and equipment, as well as several alternative bus layouts that can be used. The purpose is to make comfort and safety bus facilities.
\end{abstract}

Key word: Bus Passenger Seat, Ergonomic, Anthropometric, Concept Scoring, Bus Layout. 


\section{Pendahuluan}

Dalam persaingan bisnis sekarang ini setiap penyedia jasa layanan transportasi harus mampu untuk memberikan pelayanan yang terbaik agar dapat memuaskan para konsumennya, sehingga mereka akan mampu untuk memenangkan persaingan dengan penyedia jasa layanan transportasi lain yang sejenis.

Banyaknya pengguna bis pariwisata ini dikarenakan harga yang relatif lebih murah dan kenyamanan yang tidak kalah dibandingkan dengan transportasi laut maupun udara. Selain itu banyaknya pilihan rute perjalanan yang ditawarkan penyedia jasa juga menjadi keunggulan jenis transportasi ini. Konsumen se lalu mengharapkan agar mendapatkan service yang optimal sesuai dengan ekspektasi mereka.

Salah satu yang menjadi faktor penting bagi konsumen adalah kenyamanan fasilitas dari bis tersebut. Fasilitas kursi penumpang menjadi perhatian utama dari konsumen, hal tersebut dikarenakan sebagian besar waktu yang dihabiskan penumpang bis adalah di kursi penumpang, sehingga diperlukan kursi yang nyaman dengan fasilitas yang mendukung.

Masalah yang dihadapi oleh PT XYZ salah satunya adalah pada desain kursi penumpang yang kurang nyaman dan fasilitas pendukungnya yang masih kurang baik sehingga akan menyulitkan penumpang saat akan beraktivitas seperti makan dan minum. Maka dari itu pihak perusahaan meminta kepada penulis untuk melakukan penelitian terhadap desain kursi penumpang dan fasilitas pendukung yang memadai berdasarkan pertimbangan ergonomis.

Kenyamanan tersebut dapat dicapai dengan desain kursi penumpang yang ergonomis dengan memperhatikan antropometri tubuh manusia dan kelengkapan fasilitas pendukungnya. Dengan demikian upaya peningkatan kualitas produk secara sistematis merupakan salah satu upaya untuk memenuhi kebutuhan dan keinginan konsumen tersebut.

Berdasarkan latar belakang tersebut, penulis berusaha melakukan pembahasan mengenai penerapan prinsip-prins ip ergonomi dan perancangan produk di PT XYZ dan menganalisanya dengan harapan dapat digunakan sebagai masukan yang berarti bagi perusahaan.

\section{Tinjauan Pustaka}

Wawancara digunakan sebagai teknik pengumpulan data apabila peneliti ingin melakukan studi pendahuluan untuk menemukan permasalahan yang harus diteliti, dan juga apabila peneliti ingin mengetahui hal-hal dari responden yang lebih mendalam dan jumlah respondennya sedikit/kecil. (Sugiyono,157).

Pada dasarnya, ergonomi ialah suatu cabang ilmu yang sistematis untuk memanfaatkan informasiinformasi mengenai sifat, kemampuan, dan keterbatasan manusia untuk merancang suatu sistem kerja sehingga orang dapat hidup dan bekerja pada sistem itu dengan baik, yaitu mencapai tujuan yang diinginkan melalui pekerjaan itu, dengan efektif, aman, sehat, nyaman, dan efisien. (Sutalaksana,72)

Menurut Stevenson (1989) dan Nurmianto (1991), antropometri adalah suatu kumpulan data numerik yang berhubungan dengan karakteristik fisik tubuh manusia, ukuran, bentuk dan kekuatan serta penerapan dari data tersebut untuk penanganan masalah desain. (Sutalaksana,54)

Persentil adalah suatu nilai yang menyatakan persentase tertentu dari sekelompok orang yang memiliki dimensi tubuh yang ukurannya sama atau lebih kecil dari nilai tesebut. (Nurmianto,55) Morris Asimow menerangkan perancangan teknik adalah suatu aktivitas dengan maksud tertentu menuju ke arah tujuan dari pemenuhan kebutuhan manusia, terutama yang dapat diterima oleh faktor teknologi peradaban kita. (Tim Asisten Lab APK \& E,8)

Duduk memerlukan lebih sedikit energi daripada berdiri, karena hal itu dapat mengurangi banyaknya beban otot statis pada kaki. Namun sikap duduk yang keliru merupakan penyebab adanya masalah-masalah pada punggung. Tekanan pada bagian tulang belakang akan meningkat pada saat duduk, dibandingkan dengan saat berdiri ataupun berbaring. Kenaikan tekanan dapat meningkat dari suatu perubahan lekukan tulang be lakang yang terjadi pada saat duduk. 
Penilaian konsep dilakukan untuk mengetahui konsep produk manakah yang terbaik diantara beberapa konsep produk yang dibandingkan, berdasarkan kriteria seleksi tertentu.

Hazard adalah suatu objek dimana terdapat energi, zat, atau kondisi kerja yang potensial dapat mengancam keselamatan. Hazard dapat berupa bahan-bahan, bagian-bagian mes in, bentuk energi, metode kerja, atau situasi kerja. Hazard adalah sumber bahan potensial yang dapat menyebabkan kerusakan. $(7,5)$ Harm adalah kerusakan atau bentuk kerugian berupa kematian, cidera, sakit fisik, atau mental, kerusakan properti, kerugian produksi, kerusakan lingkungan, atau kombinasi dari kerugian-kerugian tadi. Safe adalah suatu kondisi dimana atau kapan munculnya sumber bahaya telah dapat dikendalikan ke tingkat yang memadai, dan ini adalah lawan dari bahaya. Danger adalah suatu kondisi yang te lah teridentif ikasi me lalui pemeriksaan/pengujian/ana lis is disimpulkan telah menunjukan melampaui batas aman. Danger adalah lawan dari aman atau selamat.

Incident adalah suatu keadaan/kondisi bilamana pada saat itu sedikit saja ada perubahan maka dapat mengakibatkan terjadinya kecelakaan/accident. Accident adalah kejadiannya tiba-tiba, tidak diduga, dan tidak dikehendaki, mengganggu proses bahkan menimbulkan kerugian. Risk adalah ukuran kemungkinan kerugian yang akan timbul dari sumber bahaya tertentu yang terjadi. Untuk menentukan resiko membutuhkan perhitungan antara konsekuensi/dampak yang mungkin timbul dan probabilitas, yang biasanya disebut sebagai tingkat resiko (level of risk). Kesehatan merupakan derajat atau tingkat keadaan fisik dan psikologi individu (the degree of physicological and physiological well being of the individual).

\section{Metodologi Pene litian}
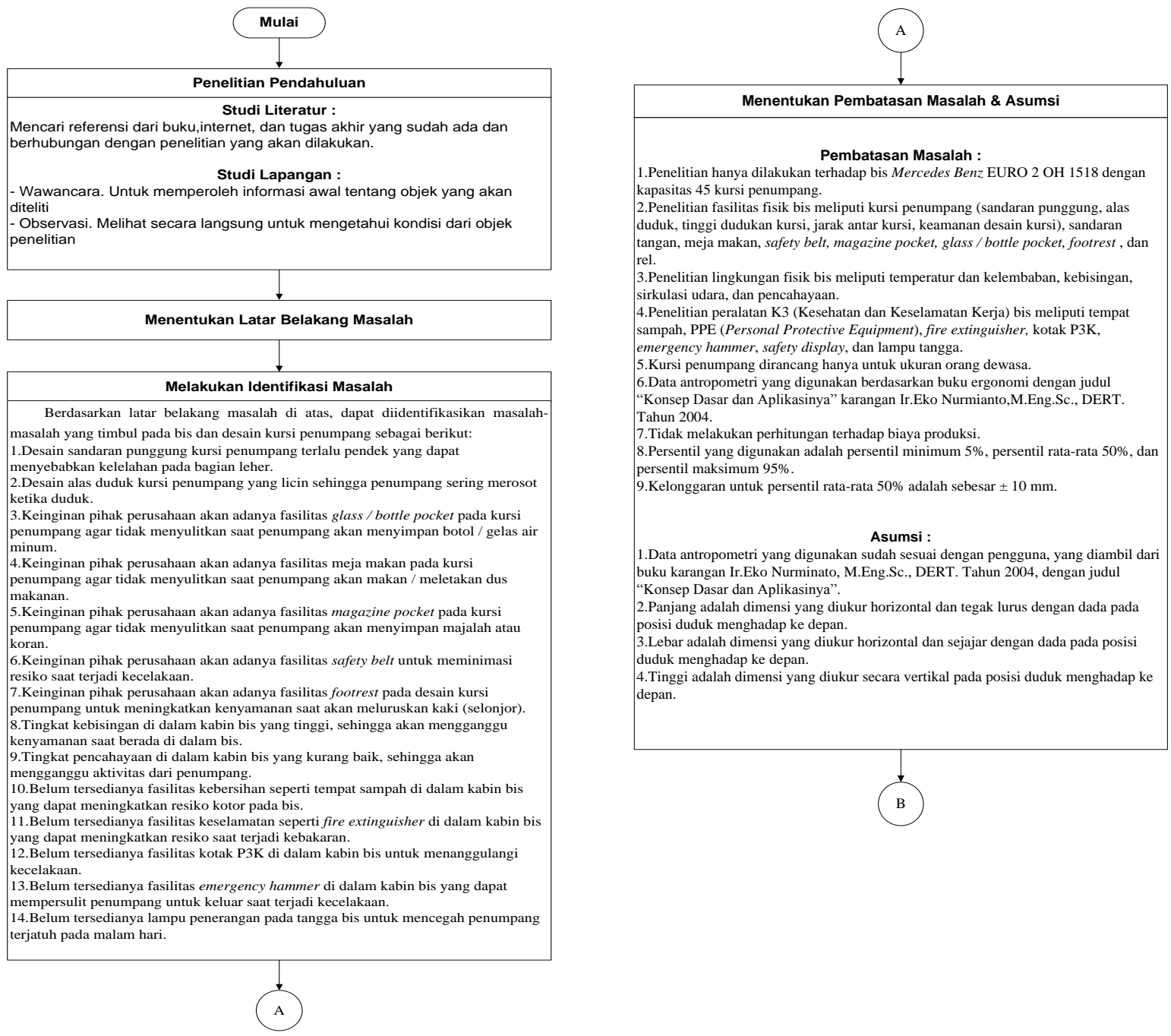

Gambar 1. Metodologi Penelitian 

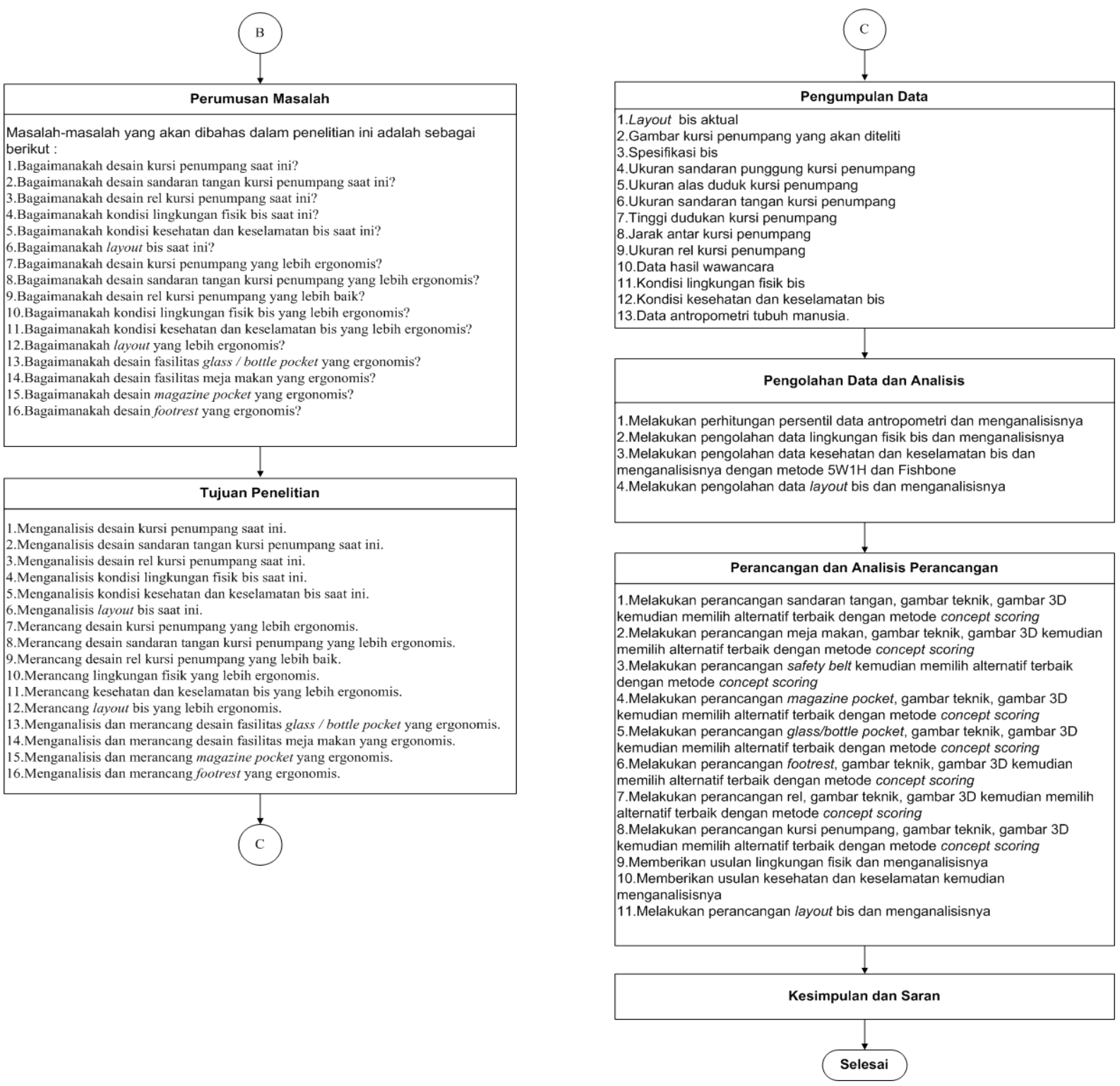

Gambar 1. Metodologi Penelitian (Lanjutan)

\section{Pengumpulan Data}

\subsection{Data Spesifikasi dan Fasilitas Fisik B is}

\subsubsection{Layout B is Aktual}

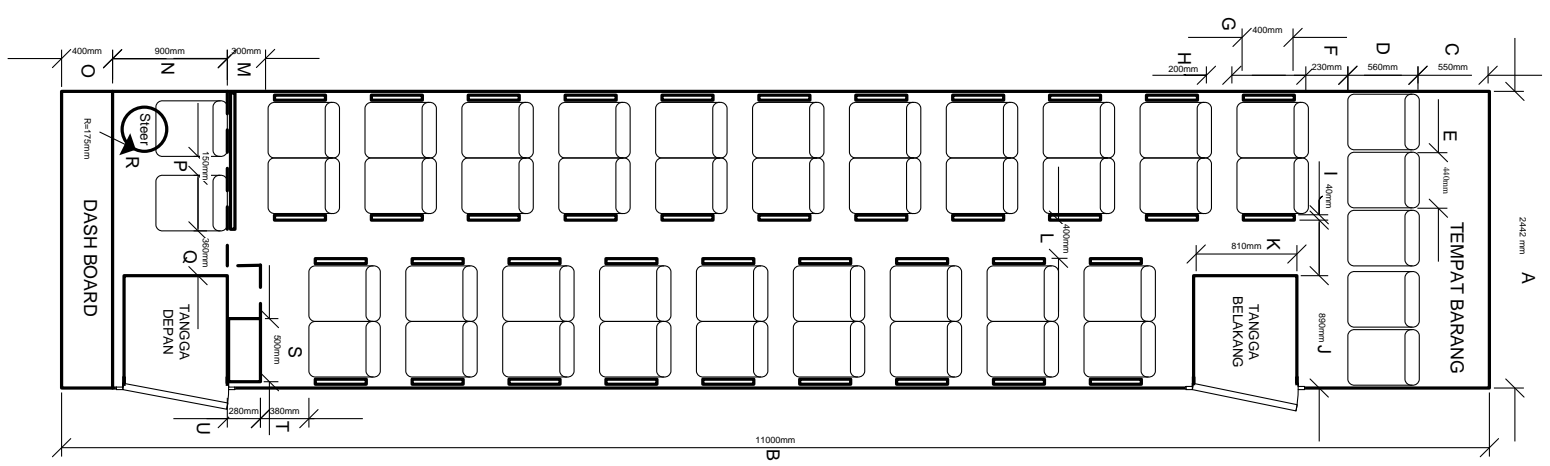

Gambar 2. Layout Bis Tampak Atas (Skala 1:100) 


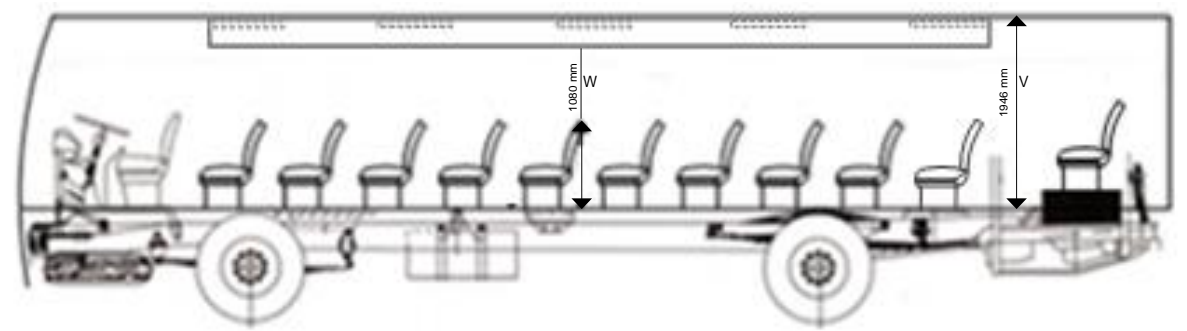

Gambar 3. Layout Bis Tampak Samping (Skala 1:100)

Tabel 1. Keterangan Gambar Layout Bis

\begin{tabular}{|c|c|c|}
\hline Huruf & Keterangan & Ukuran (mm) \\
\hline $\mathrm{A}$ & Lebar bis & 2.442 \\
\hline $\mathrm{B}$ & Panjang Bis & 11.000 \\
\hline $\mathrm{C}$ & $\begin{array}{l}\text { Panjang dari tempat penyimpanan barang yang } \\
\text { berada di belakang kursi penumpang }\end{array}$ & 550 \\
\hline $\mathrm{D}$ & Panjang total kursi penumpang & 520 \\
\hline $\mathrm{E}$ & Lebar dari kursi penumpang & 440 \\
\hline F & $\begin{array}{l}\text { Jarak antara kursi penumpang bagian belakang } \\
\text { dengan kursi penumpang di sisi sebelah kanan }\end{array}$ & 230 \\
\hline $\mathrm{G}$ & Panjang dari sandaran tangan kursi penumpang & 400 \\
\hline $\mathrm{H}$ & Jarak antar kursi penumpang & 238 \\
\hline I & Lebar dari sandaran tangan & 40 \\
\hline $\mathrm{J}$ & Lebar dari tangga belakang bis & 890 \\
\hline $\mathrm{K}$ & Panjang dari tangga belakang bis & 810 \\
\hline $\mathrm{L}$ & $\begin{array}{l}\text { Lebar dari gang yang memisahkan antara rangkaian } \\
\text { kursi di sebelah kiri dengan di sebelah kanan }\end{array}$ & 400 \\
\hline M & $\begin{array}{l}\text { Jarak antara kursi pengemudi dengan kursi } \\
\text { penumpang di sebelah kanan }\end{array}$ & 300 \\
\hline $\mathrm{N}$ & Jarak antara kursi pengemudi dengan dashboard & 900 \\
\hline $\mathrm{O}$ & Panjang dari dashboard & 400 \\
\hline $\mathrm{P}$ & Jarak antara kursi pengemudi dengan kursi kernet & 150 \\
\hline Q & $\begin{array}{l}\text { Jarak antara kursi kernet dengan bibir tangga bagian } \\
\text { depan }\end{array}$ & 360 \\
\hline $\mathrm{R}$ & Jari-jari dari kemudi bis & 175 \\
\hline $\mathrm{S}$ & Lebar dari box & 500 \\
\hline $\mathrm{T}$ & $\begin{array}{l}\text { Jarak antara kursi penumpang di sisi bagian kiri } \\
\text { dengan } b o x\end{array}$ & 380 \\
\hline $\mathrm{U}$ & Panjang dari $b o x$ & 280 \\
\hline $\mathrm{V}$ & Tinggi kabin bus & 1.946 \\
\hline $\mathrm{W}$ & Tinggi kursi & 1.080 \\
\hline
\end{tabular}

\subsubsection{Fasilitas Fisik Bis}

Tabel 2. Spesifikasi Sandaran Punggung

\begin{tabular}{|c|c|c||}
\hline No & Dimensi & Ukuran (mm) \\
\hline \hline 1 & Tebal Sandaran & 100 \\
\hline 2 & Lebar Sandaran & 420 \\
\hline 3 & Tinggi Sandaran & 680 \\
\hline & Kemiringan & $100^{\circ}$ \\
\hline & Fungsi & Sebagai penyangga bagian punggung \\
\hline & Bahan & Besi, busa, dan kain pelapis \\
\hline & Warna & Biru dan hijau \\
\hline \hline
\end{tabular}

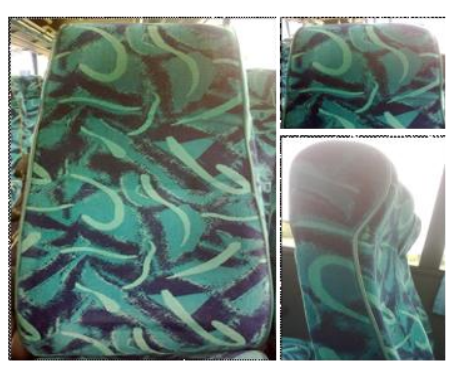

Gambar 4. Sandaran Punggung

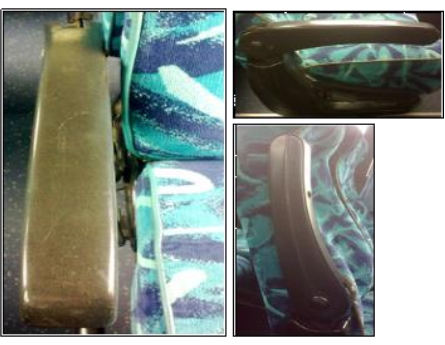

Gambar 5. Sandaran tangan

\begin{tabular}{|c|c|c||}
\hline No & Dimensi & Ukuran (mm) \\
\hline \hline 1 & Panjang & 400 \\
\hline 2 & Lebar & 40 \\
\hline 3 & Tinggi & 50 \\
\hline & Fungsi & Sebagai penyangga bagian tangan \\
\hline Bahan & Besi dan plastik \\
\hline Warna & Hitam \\
\hline \hline
\end{tabular}


ANALIS IS DAN PERANCANGAN KURS I PENUMPANG B IS PARIWISATA (Wawan Y., dkk)

Tabel 4. Spesifikasi Alas Duduk

\begin{tabular}{|c|c|c||}
\hline No & Dimensi & Ukuran (mm) \\
\hline \hline 1 & Panjang & 420 \\
\hline 2 & Lebar & 440 \\
\hline 3 & Tebal & 100 \\
\hline & Fungsi & Sebagai alas untuk duduk \\
\hline & Bahan & Besi, busa, dan kain pelapis \\
\hline & Warna & Biru dan hijau \\
\hline
\end{tabular}

Tabel 5. Jarak Antar Kursi

\begin{tabular}{|c|c|c|c|c||}
\hline \multicolumn{2}{|c|}{ Normal } & & \multicolumn{2}{c||}{ Reclining } \\
\cline { 1 - 2 } Huruf & Ukuran (mm) & Huruf & Ukuran (mm) \\
\hline \hline A & 238 & & A & 278 \\
\hline B & 635 & B & 620 \\
\hline C & 665 & C & 650 \\
\hline
\end{tabular}

Tabel 6. Spesifikasi Rangka Kursi

\begin{tabular}{|c|c|c|}
\hline No & Dimensi & Ukuran (mm) \\
\hline 1 & Panjang & 420 \\
\hline 2 & Lebar & 880 \\
\hline & Fungsi & $\begin{array}{l}\text { Sebagai rangka untuk alas duduk, } \\
\text { dudukan kursi, dan sandaran tangan }\end{array}$ \\
\hline & Bahan & Besi hollow \\
\hline & Warna & Hitam \\
\hline
\end{tabular}

Tabel 7. Spesifikasi Dudukan Kursi

\begin{tabular}{|c|c|c||}
\hline No & Dimensi & Ukuran (mm) \\
\hline \hline 1 & Panjang & 240 \\
\hline 2 & Lebar & 30 \\
\hline 3 & Tinggi & 280 \\
\hline & Fungsi & Sebagai penyangga kursi bis \\
\hline Bahan & Besi cor \\
\hline \multicolumn{2}{|c|}{ Warna } & Hitam \\
\hline \hline
\end{tabular}

Tabel 8. Spesifikasi Rel

\begin{tabular}{|c|c|c|c|c|c||}
\hline \multicolumn{3}{|c|}{ Sisi Kiri } & \multicolumn{3}{|c|}{ Sisi Kanan } \\
\cline { 1 - 3 } No & Dimensi & Ukuran (mm) & No & Dimensi & Ukuran (mm) \\
\hline \hline 1 & Panjang & 7150 & 1 & Panjang & 7940 \\
\hline 2 & Lebar & 50 & 2 & Lebar & 50 \\
\hline 3 & Tinggi & 20 & 3 & Tinggi & 20 \\
\hline \multicolumn{2}{|c|}{ Fungsi } & Sebagai lintasan dan tempat mengunci kursi bis \\
\hline \multicolumn{2}{|c|}{ Bahan } & \multicolumn{4}{|c|}{ Alumunium } \\
\hline \multicolumn{2}{|c|}{ Warna } & \multicolumn{3}{|c|}{ Silver } \\
\hline \hline
\end{tabular}

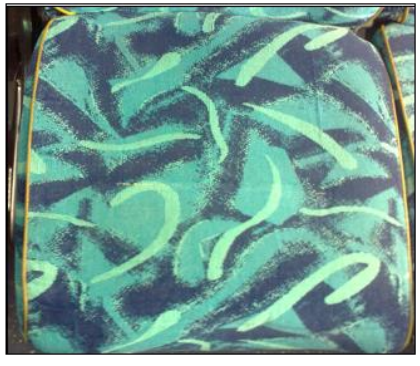

Gambar 6. Alas Duduk
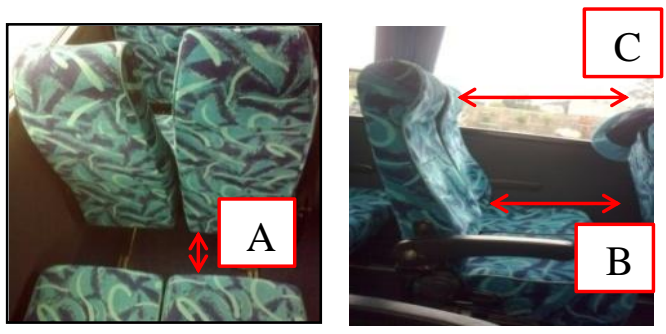

Gambar 7. Jarak Antar Kursi

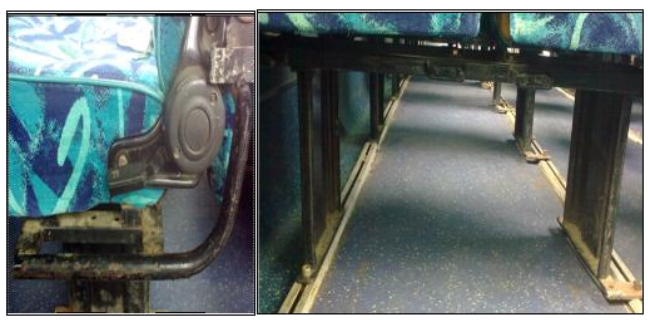

Gambar 8. Gambar Rangka Kursi

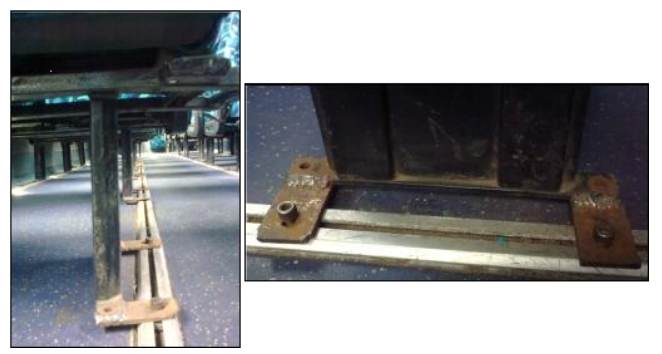

Gambar 9. Dudukan Kursi

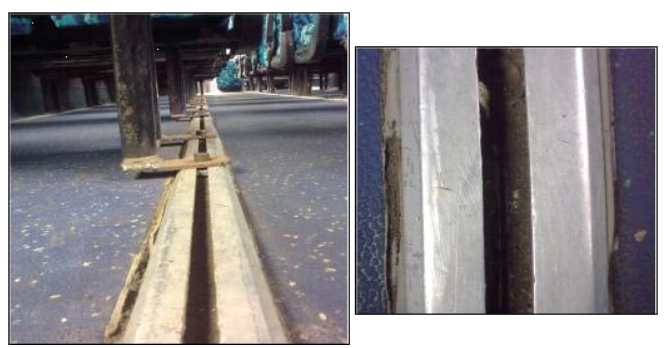

Gambar 10. Gambar Rel 
Tabel 9. Ukuran Gang

\begin{tabular}{|c|c|}
\hline Huruf & Ukuran (mm) \\
\hline \hline A & 400 \\
\hline B & 440 \\
\hline C & 460 \\
\hline
\end{tabular}

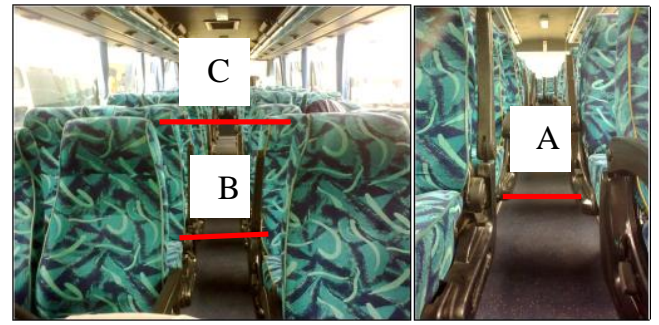

Gambar 11. Lebar Gang

\subsection{Kesehatan dan Keselamatan Kerja}

Tabel 10. Kesehatan dan Keselamatan Bis

\begin{tabular}{|c|c|c|c|c|}
\hline $\begin{array}{l}\text { Pernah } \\
\text { Terjadi }\end{array}$ & Penyebab & Akibat & Pencegahan & Penanggulangan \\
\hline Terjatuh & $\begin{array}{l}\text { Kurang hati-hati } \\
\text { saat naik/turun bis }\end{array}$ & $\begin{array}{l}\text { Memar pada } \\
\text { Anggota Tubuh }\end{array}$ & $\begin{array}{l}\text { Memberi Himbauan } \\
\text { pada Penumpang }\end{array}$ & $\begin{array}{l}\text { Belum ada Upaya } \\
\text { Penanggulangan }\end{array}$ \\
\hline \multicolumn{5}{|l|}{$\begin{array}{l}\text { Berpotensi } \\
\text { Terjadi }\end{array}$} \\
\hline Kebakaran & $\begin{array}{l}\text { Konsleting Listrik, } \\
\text { Instalasi yang } \\
\text { Tidak Baik, } \\
\text { Puntung Rokok }\end{array}$ & $\begin{array}{l}\text { Kerusakan Bis, } \\
\text { Luka Bakar, } \\
\text { Cacat Tubuh, } \\
\text { Meninggal Dunia }\end{array}$ & $\begin{array}{l}\text { Pemeriksaan } \\
\text { Berkala Terhadap } \\
\text { Instalasi Listrik }\end{array}$ & $\begin{array}{l}\text { Belum ada Upaya } \\
\text { Penanggulangan }\end{array}$ \\
\hline Tertabrak & $\begin{array}{l}\text { Kendaraan Lain, } \\
\text { Jalan Sempit, } \\
\text { Kendaraan Melaju } \\
\text { Kencang }\end{array}$ & $\begin{array}{l}\text { Kerusakan Bis, } \\
\text { Cacat Tubuh, } \\
\text { Meninggal Dunia }\end{array}$ & $\begin{array}{l}\text { Menghimbau } \\
\text { Pengemudi untuk } \\
\text { Berhati-hati }\end{array}$ & $\begin{array}{l}\text { Belum ada Upaya } \\
\text { Penanggulangan }\end{array}$ \\
\hline Terjatuh & $\begin{array}{l}\text { Tersandung Rel, } \\
\text { Pencahayaan } \\
\text { Kurang Baik, } \\
\text { Kurang Berhati- } \\
\text { hati }\end{array}$ & $\begin{array}{l}\text { Memar pada } \\
\text { Tubuh,Patah } \\
\text { Tulang }\end{array}$ & $\begin{array}{l}\text { Belum Ada Upaya } \\
\text { Pencegahan }\end{array}$ & $\begin{array}{l}\text { Belum ada Upaya } \\
\text { Penanggulangan }\end{array}$ \\
\hline
\end{tabular}

\section{Pengolahan Data dan Analis is}

5.1 Analis is Fasilitas Fisik dan Pemilihan Ukuran untuk Perancangan Kursi Penumpang B is dan Fasilitas Pendukungnya.

Tabel 11. Data Antropometri Dalam Perancangan Kursi dan Fasilitas Pendukung

\begin{tabular}{|c|c|c|c|c|c|c|c|c|c|c|}
\hline \multirow{2}{*}{ No } & \multirow{2}{*}{ Data Antropometri } & \multicolumn{3}{|c|}{ Pria (mm) } & \multicolumn{3}{|c|}{ Wanita (mm) } & \multicolumn{3}{|c|}{ Pria \& Wanita (mm) } \\
\hline & & $5 \%$ & $50 \%$ & $95 \%$ & $5 \%$ & $50 \%$ & $95 \%$ & $5 \%$ & $50 \%$ & $95 \%$ \\
\hline 1 & Tinggi Badan pada Posisi Duduk (TBPD) & 809 & 864 & 919 & 775 & 834 & 893 & 775 & 849 & 919 \\
\hline 2 & Lebar Bahu ( Bideltoid) (LB)) & 382 & 424 & 466 & 342 & 385 & 428 & 342 & 404.5 & 466 \\
\hline 3 & Tinggi Bahu pada Posisi Duduk (TBD) & 523 & 572 & 621 & 501 & 550 & 599 & 501 & 561 & 621 \\
\hline 4 & Tinggi Mata pada Posisi Duduk (TMD) & 694 & 749 & 804 & 666 & 721 & 776 & 666 & 735 & 804 \\
\hline 5 & Lebar Panggul (LP) & 291 & 331 & 371 & 298 & 345 & 392 & 291 & 338 & 392 \\
\hline 6 & Jarak dari Lipat Lutut ( Popliteal) ke Pantat (PP) & 405 & 450 & 495 & 488 & 537 & 586 & 405 & 493.5 & 586 \\
\hline 7 & Tinggi Siku pada Posisi Duduk (TSD) & 181 & 231 & 282 & 175 & 229 & 283 & 175 & 230 & 283 \\
\hline 8 & Jarak dari Siku ke Ujung Jari & 405 & 439 & 473 & 374 & 409 & 287 & 374 & 424 & 473 \\
\hline 9 & Lebar Telapak Tangan (minim & 68 & 75 & 82 & 64 & 59 & 74 & 64 & 67 & 82 \\
\hline 10 & Tebal Paha (TP) & 117 & 140 & 163 & 115 & 140 & 165 & 115 & 140 & 165 \\
\hline 11 & Tebal Dada (TD) & 174 & 212 & 250 & 178 & 228 & 278 & 174 & 220 & 278 \\
\hline 12 & $\begin{array}{l}\text { Jarak Genggaman Tangan ( Grip ) ke Punggung } \\
\text { Pada Posisi Tangan ke Depan ( Horisontal) }\end{array}$ & 649 & 708 & 767 & 610 & 661 & 712 & 610 & 684.5 & 767 \\
\hline 13 & Dieameter Genggam (maksimum) & 45 & 48 & 51 & 43 & 46 & 49 & 43 & 47 & 51 \\
\hline 14 & Tinggi Lipat Lutut ( Popliteal ) (TPO)) & 361 & 403 & 445 & 337 & 382 & 428 & 337 & 392.5 & 445 \\
\hline 15 & Lebar Kaki & 82 & 89 & 96 & 81 & 88 & 95 & 81 & 88.5 & 96 \\
\hline 16 & Panjang Telapak Kaki & 230 & 248 & 266 & 212 & 230 & 248 & 212 & 239 & 266 \\
\hline
\end{tabular}

Contoh perhitungan persentil $50 \%$ untuk TBPD :

$(864+834) / 2=849$ 
ANALIS IS DAN PERANCANGAN KURS I PENUMPANG B IS PARIWISATA (Wawan Y., dkk)

Tabel 12. Antropometri/Data Acuan Lain Kursi Penumpang

\begin{tabular}{|c|c|c|c|c|c|c|c|c|c|c|c|}
\hline \multirow{2}{*}{ Jenis } & \multicolumn{3}{|c|}{ Dimensi (mm) } & \multirow[t]{2}{*}{ Patokan } & \multirow{2}{*}{$\begin{array}{c}\text { Data Antropometri / Data Acuan Lainnya } \\
\text { Jenis }\end{array}$} & \multirow{2}{*}{ Persentil } & \multirow{2}{*}{ Ukuran (mm) } & \multicolumn{2}{|c|}{ Allowance } & \multirow{2}{*}{$\begin{array}{c}\text { Keputusan } \\
\text { Antropometri (mm) }\end{array}$} & \multirow{2}{*}{ Analisis } \\
\hline & & Jenis & Ukuran Aktual & & & & & Jenis & Ukuran (mm) & & \\
\hline \multirow{15}{*}{$\begin{array}{c}\text { Kursi } \\
\text { Penumpang }\end{array}$} & \multirow{5}{*}{$\begin{array}{c}\text { Sandaran } \\
\text { Kursi }\end{array}$} & \multirow{2}{*}{ Tinggi } & \multirow{2}{*}{680} & Min & Tinggi Badan pada Posisi Duduk & 95 & 919 & - & - & \multirow{2}{*}{919 s.d 1027} & \multirow{2}{*}{ Belum sesuai } \\
\hline & & & & Max & Tinggi Kabin Bus - Tinggi Badan pada Posisi Duduk & - & 1027 & - & - & & \\
\hline & & \multirow{2}{*}{ Lebar } & \multirow{2}{*}{420} & Min & Lebar Bahu (Bideltoid) & 95 & 466 & - & - & \multirow{2}{*}{466 s.d 699} & \multirow{2}{*}{ Belum sesuai } \\
\hline & & & & $\operatorname{Max}$ & $1 \frac{1 / 2}{2} *$ Lebar Bahu (Bideltoid) & - & 699 & - & - & & \\
\hline & & Tebal & 100 & - & Tebal busa & - & - & - & - & 100 & - \\
\hline & \multicolumn{2}{|c|}{ Kemiringan } & 100 & - & $\begin{array}{c}\text { Standar buku Ergonomi "Konsep Dasar dan Aplikasinya, } \\
\text { Edisi Pertama, Karangan Eko Nurmianto }\end{array}$ & - & 110 & - & - & 110 & Belum sesuai \\
\hline & \multirow{5}{*}{ Alas Kursi } & Panjang & 420 & \pm & Jarak dari Lipat Lutut (Popliteal) ke Pantat & 50 & 493.5 & Kelonggaran & 10 & 483.5 s.d 503.5 & Belum sesuai \\
\hline & & \multirow{2}{*}{ Lebar } & \multirow{2}{*}{440} & Min & Lebar Bahu (Bideltoid) & 95 & 466 & - & - & \multirow{2}{*}{466 s.d 588} & \multirow{2}{*}{ Belum sesuai } \\
\hline & & & & Max & $1 \frac{1122}{2}$ Lebar Panggul & 95 & 588 & - & - & & \\
\hline & & \multirow{2}{*}{ Tinggi } & \multirow{2}{*}{380} & \pm & \multirow{2}{*}{ Tinggi Lipat Lutut (Popliteal) } & \multirow{2}{*}{50} & \multirow{2}{*}{392.5} & \begin{tabular}{|l|} 
Kelonggaran \\
\end{tabular} & 10 & \multirow{2}{*}{382.5 s.d 402.5} & \multirow{2}{*}{ Belum sesuai } \\
\hline & & & & $I$ & & & & Alas kaki & 10 & & \\
\hline & \multirow{4}{*}{$\begin{array}{c}\text { Sandaran } \\
\text { Tangan }\end{array}$} & Tinggi & 170 & Min & $\begin{array}{l}\text { Tinggi Siku pada Posisi Duduk } \\
\text { Tingoi Siku }\end{array}$ & 5 & $\frac{175}{202}$ & - & - & 175 s.d 283 & Belum sesuai \\
\hline & & Paniang & 400 & Min & Jarak dari Siku ke Ujung Jari & 95 & 473 & - & - & $d 58-2>$ & 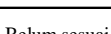 \\
\hline & & Panjang & 400 & Max & Jarak dari Lipat Lutut (Popliteal) ke Pantat & 95 & 586 & - & - & 580 & Bertum sesual \\
\hline & & Lebar & 40 & \pm & Lebar Telapak Tangan (minimum) & 50 & 77 & Kelonggaran & 10 & 67 s.d 87 & Belum sesuai \\
\hline
\end{tabular}

\subsection{Analisis Lingkungan Fisik B is}

\subsubsection{Temperatur dan Kelembaban}

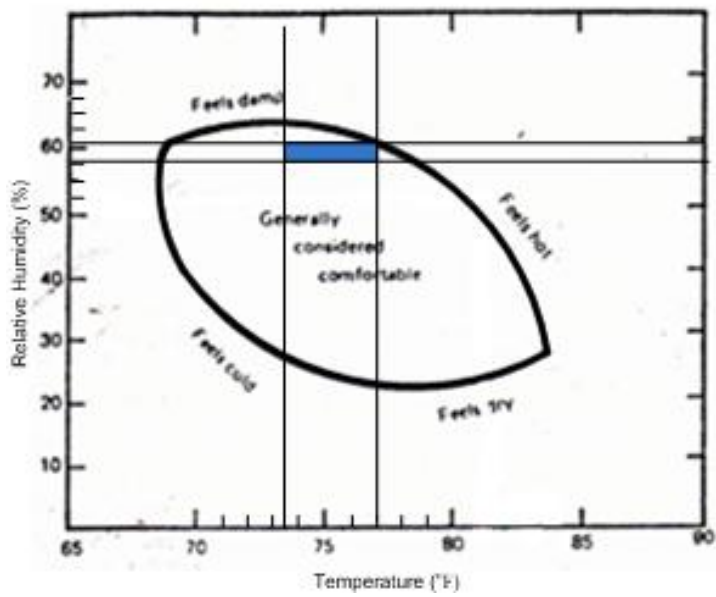

* Perhitungan konversi ${ }^{\circ} \mathrm{C} \rightarrow{ }^{\circ} \mathrm{F}$

$\left\{(9 / 5) * 23^{\circ} \mathrm{C}\right\}+32=73,4^{\circ} \mathrm{F}$

$\left\{(9 / 5) * 25^{\circ} \mathrm{C}\right\}+32=77^{\circ} \mathrm{F}$

Gambar 12. Hubungan Temperatur dengan Kelembaban Aktual

Berdasarkan Handbook of Ergonomic and Human Factors Table dapat diketahui bahwa kondisi temperatur dan kelembaban di dalam kabin bis berada dalam green zone atau zona nyaman sehingga tidak diperlukan lagi perbaikan untuk temperatur dan kelembaban.

\subsubsection{Kebisingan}

Tabel 13. Tingkat Kebisingan Bis Aktual

\begin{tabular}{|c|c|}
\hline Daerah & Tingkat Kebisingan (dB) \\
\hline \hline Belakang & 89 \\
\hline Tengah & 86 \\
\hline Depan & 81 \\
\hline \hline
\end{tabular}

Berdasarkan klasifikasi kebisingan menurut Furrer dapat diketahui bahwa tingkat kebisingan bis masuk kedalam kategori sangat berisik. Dan hal tersebut tentu sangat membutuhkan perbaikan agar diperoleh hasil yang lebih baik dengan kondisi bis yang tenang dan penumpang dapat nyaman ketika berada di dalam bis.

\subsubsection{Sirkulasi Udara}

Sirkulasi udara sudah cukup baik karena aliran udara tersebar merata karena di dalam kabin bis terdapat blower yang berfungsi mengalirkan udara ke seluruh bagian kabin bis. Maka dari itu tidak diperlukan perbaikan untuk sirkulasi udara di dalam kabin bis karena sudah cukup baik. 


\subsubsection{Pencahayaan}

Hasil pengukuran menunjukan bahwa penerangan di kabin bis berkisar antara 27 lux - 36 lux, tingkat pencahayaan tersebut merupakan pencahayaan yang diterima di kursi penumpang yang berada dekat dengan kaca. Berdasarkan Handbook of Ergonomic and Human Factors Table mengenai tingkat pencahayaan minimal 75 lux, maka dapat diketahui bahwa tingkat pencahayaan di kabin bis tidak memenuhi syarat sehingga perlu dilakukan perbaikan dengan penambahan jumlah lampu atau mengganti daya lampu agar pencahayaan lebih baik dan penumpang dapat beraktivitas dengan baik.

\subsection{Kesehatan dan Keselamatan Kerja \\ 5.3.1 Metode 5W1H}

Untuk jenis kecelakaan yang pernah terjadi adalah:

- Terjatuh

- What : Permasalahan utama adalah terjatuh.

- Why : Kecelakaan dapat terjadi karena orang kurang berhati-hati ketika naik atau turun tangga.

- Where : Kecelakaan dapat terjadi di dalam kabin bis maupun ketika berada di luar bis.

- When : Kecelakaan dapat terjadi saat naik atau turun tangga.

- Who : Kecelakaan dapat terjadi pada siapa saja baik penumpang maupun pengemudi bis yang tidak berhati-hati.

- How : Kecelakaan ini dapat terjadi disebabkan kekurang hati-hatian orang saat naik atau turun tangga karena tangga yang licin.

Untuk jenis kecelakaan yang berpotensi terjadi diantaranya:

- Kebakaran

- What : Permasalahan utama adalah kebakaran.

- Why : Kecelakaan dapat terjadi akibat konsleting listrik karena instalasi yang tidak terawat dengan baik, kondisi fisik bis yang tidak dirawat dengan baik, dan kecerobohan orang membuang puntung rokok sembarangan dalam keadaan masih menyala.

- Where : Kecelakaan dapat terjadi di dalam kabin bis maupun di tempat terdapat mesin bis.

- When : Kecelakaan dapat terjadi ketika terjadi konsleting listrik, ketika terjadi masalah pada mesin bis, dan ketika tersulut puntung rokok.

- Who : Kecelakaan dapat terjadi karena tidak dilakukan perawatan secara berkala oleh pekerja dan disebabkan kelalaian orang lain.

- How : Kecelakaan dapat terjadi karena kurang dilakukannya perawatan terhadap instalasi listrik oleh pekerja, sehingga kemungkinan terjadinya konsleting akan semakin besar dan karena kecerobohan orang lain membuang puntung rokok sembarangan dalam keadaan masih menyala yang dapat membakar peralatan pada bis, juga ketidaktersediaan alat pemadam kebakaran.

- Tertabrak

- What : Permasalahan utama adalah tertabrak.

- Why : Kecelakaan ini dapat terjadi akibat kekurang hati-hatian pengemudi saat berkendara, pengemudi yang mengantuk, berkendara dalam kecepatan tinggi, pengemudi yang kurang terampil, kesalahan dari pengendara kendaraan lain, dan tidak mematuhi peraturan lalu lintas.

- Where : Kecelakaan ini dapat terjadi dimana saja, baik ketika berjalan di jalan raya, jalan tol, maupun di jalan sempit.

- When : Kecelakaan ini dapat terjadi kapan saja, baik ketika pengemudi tidak mematuhi peraturan lalu lintas, saat pengemudi bis ataupun pengemudi kendaraan lain tidak berhatihati, maupun ketika bis sedang diam/terparkir.

- Who: Kecelakaan ini dapat terjadi oleh pengemudi bis maupun pengemudi kendaraan lain.

- How : Kecelakaan ini dapat terjadi ketika pengemudi terlalu lelah dan mengantuk atau pengemudi melanggar peraturan lalu lintas sehingga kecelakaan terjadi. 
- Terjatuh

- What : Permasalahan utama adalah terjatuh.

- Why : Kecelakaan dapat terjadi karena orang kurang berhati-hati ketika berjalan di dalam kabin bis, dan akibat tersandung bagian rel yang menonjol keluar.

- Where : Kecelakaan dapat terjadi di dalam kabin bis.

- When :Kecelakaan dapat terjadi ketika berjalan di dalam kabin bis.

- Who : Kecelakaan dapat terjadi pada siapa saja baik penumpang maupun pengemudi bis yang tidak berhati-hati.

- How : Kecelakaan ini dapat terjadi karena kekurang hati-hatian orang yang disebabkanoleh alas lantai kabin yang lic in.

\subsubsection{Metode Fishbone}

Untuk jenis kecelakaan yang pernah terjadi:

- Terjatuh

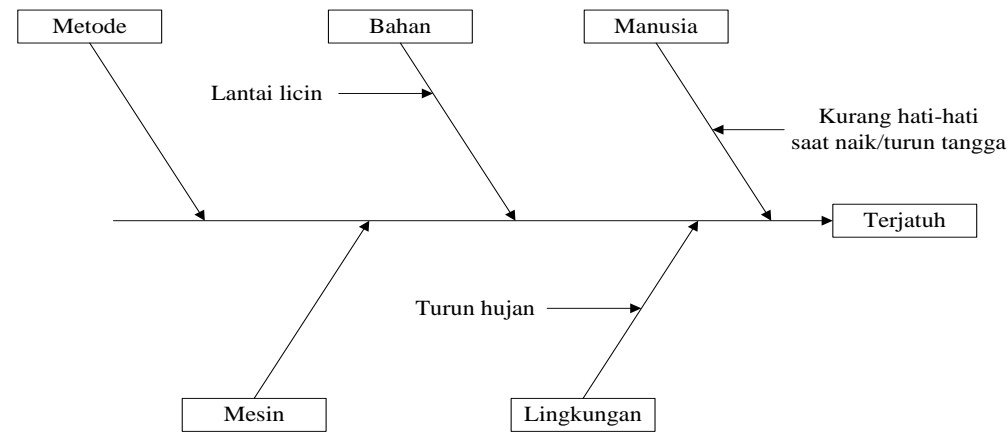

Gambar 13. Diagram Fishbone Terjatuh 3

Untuk jenis kecelakaan yang berpotensi terjadi diantaranya:

- Kebakaran

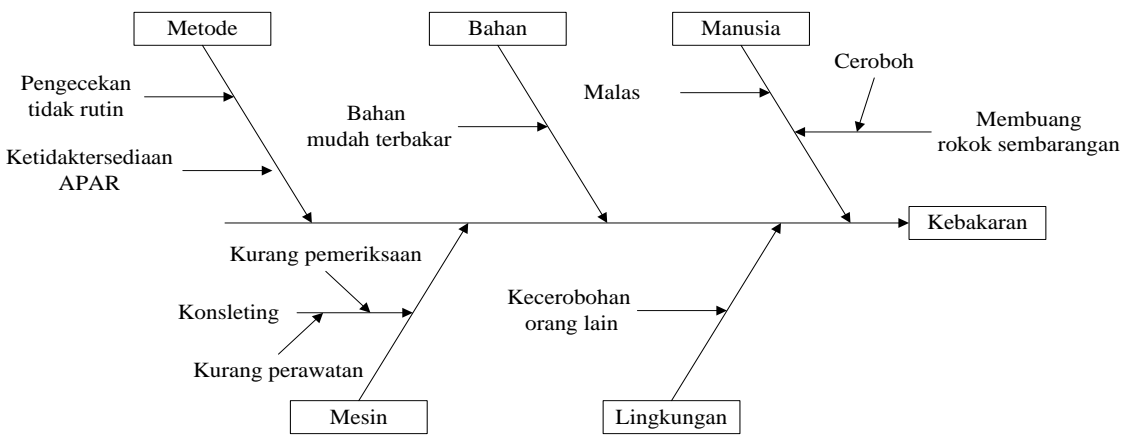

Gambar 14. Diagram Fishbone Kebakaran 2

- Tertabrak

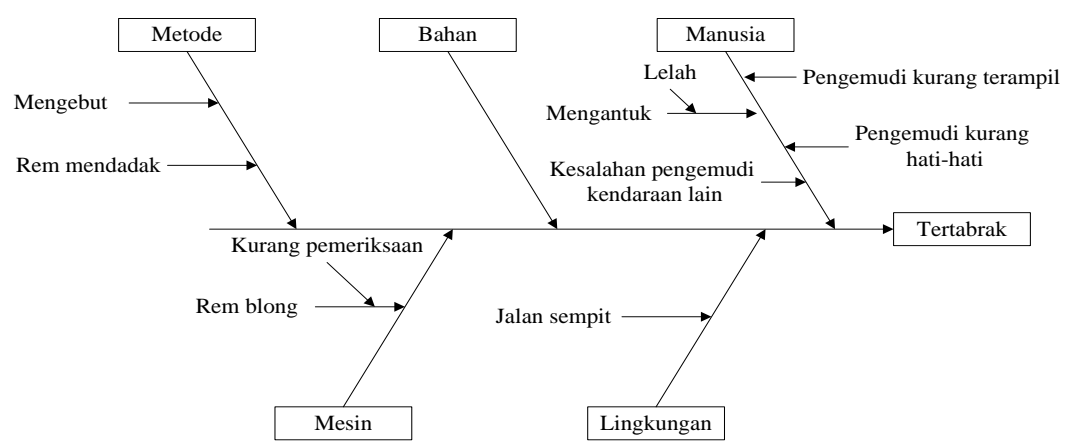

Gambar 15. Diagram Fishbone Tertabrak 2 
- Terjatuh

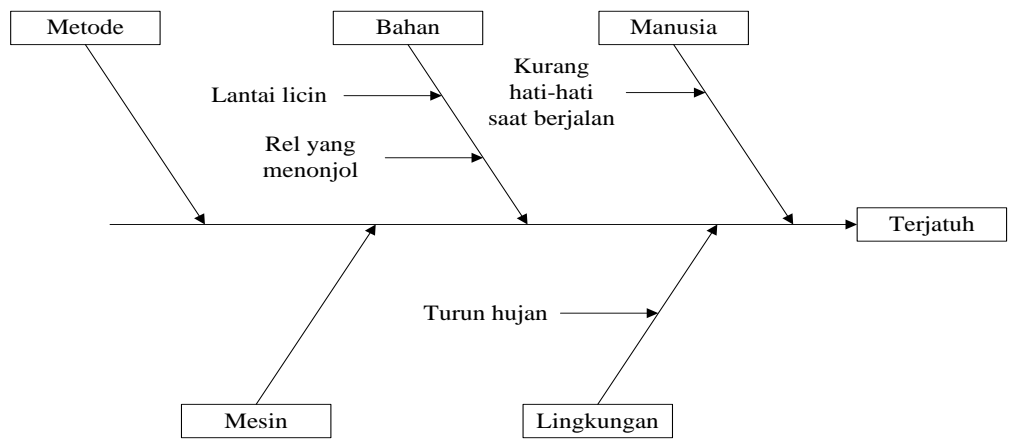

Gambar 16. Diagram Fishbone Terjatuh 4

\subsection{Analis is Layout B is}

Pada bis yang menjadi objek penelitian terdapat tiga buah pintu, yaitu pintu untuk pengemudi dan dua pintu di depan dan belakang untuk akses keluar masuk penumpang. Di dalam kabin bis diletakan kursi penumpang yang berjumlah 45 buah, 1 kursi untuk kernet, dan 1 kursi untuk pengemudi. Jumlah kursi di dalam kabin bis dapat diatur karena terdapat rel sehingga bisa dilakukan bongkar pasang.

Dari segi keleluasaan, jarak antar kursi penumpang sebesar $238 \mathrm{~mm}$ dan lebar gang sebesar 400 $\mathrm{mm}$. Jarak kursi penumpang dan lebar gang tidak dapat optimal karena berkaitan dengan luas dari kabin bis itu sendiri yang terbatas dan juga pertimbangan ekonomis.

Dari segi keselamatan, belum terdapat PPE (Personel Protective Equipment), fire extinguisher, emergency hammer, kotak P3K,dan lampu tangga sehingga dapat dikatakan keselamatan pada bis masih kurang baik.

Dari segi keamanan, bis belum dilengkapi dengan safety belt sehingga keamanan penumpang masih kurang baik, padahal safety belt dapat mencegah dan mengurangi dampak yang timbul ketika terjadi suatu kecelakaan seperti bertabrakan dengan kendaraan lain.

Dari segi kemudahan perawatan, kursi penumpang yang tidak bisa dilipat menyebabkan proses pembersihan akan sedikit terhambat karena sulit saat membersihkan bagian bawah kursi.

\section{Perancangan dan Analis is Pe rancangan \\ 6.1 Pe rancangan Fasilitas Fisik Bis \\ 6.1.1 Sandaran Tangan}
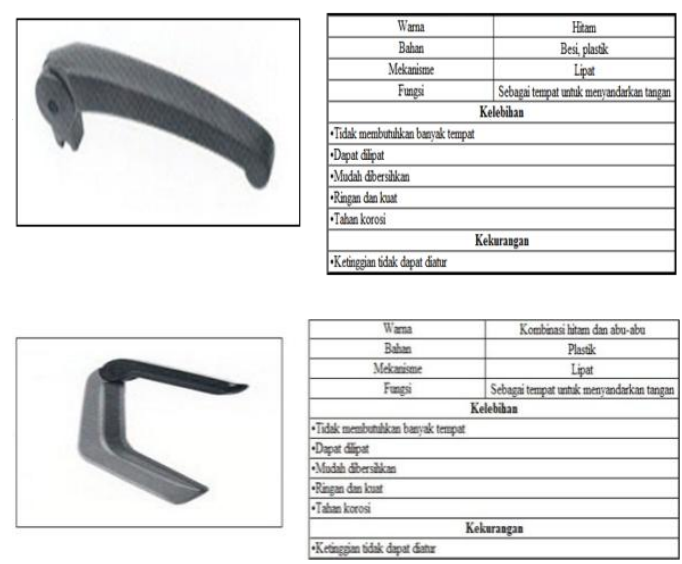
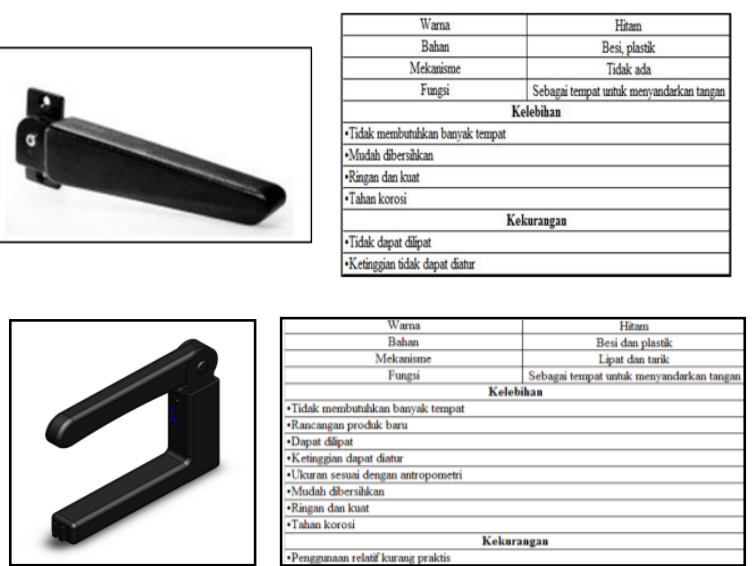

Gambar 17. Usulan Sandaran Tangan 
ANALIS IS DAN PERANCANGAN KURS I PENUMPANG B IS PARIWISATA (Wawan Y., dkk)

Tabel 14. Concept Scoring Sandaran Tangan

\begin{tabular}{|c|c|c|c|c|c||}
\hline \multirow{2}{*}{ No } & \multirow{2}{*}{ Kriteria Penilaian } & \multicolumn{5}{|c||}{ Rancangan } \\
\cline { 3 - 6 } & & Alternatif 1 & Alternatif 2 & Alternatif 3 & Alternatif 4 \\
\cline { 3 - 6 } & Rating & Rating & Rating & Rating \\
\hline 1 & Flexibilitas & 3 & 1 & 2 & 4 \\
\hline 2 & Kepraktisan & 3 & 4 & 2 & 1 \\
\hline 3 & Kesesuaian data & 2 & 3 & 1 & 4 \\
\hline & Total Nilai & 8 & 8 & 5 & 9 \\
\hline & Peringkat & 2 & 3 & 4 & 1 \\
\hline
\end{tabular}

\subsubsection{Meja Makan}
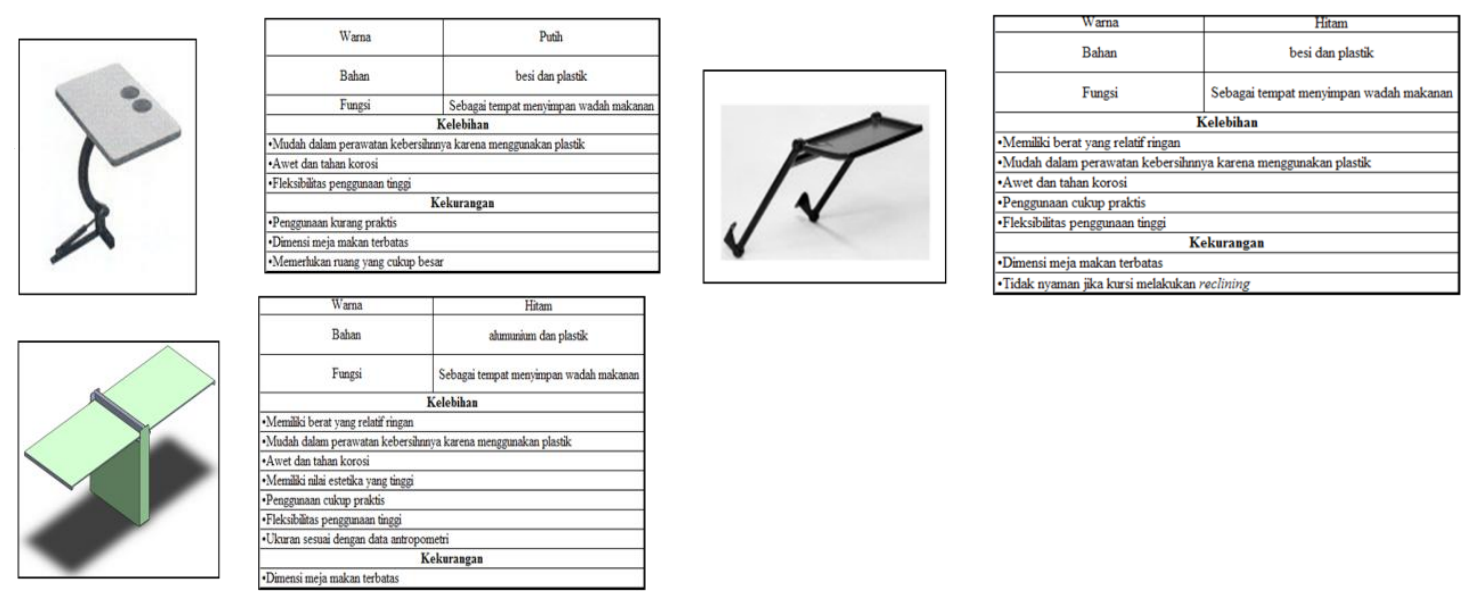

Gambar 18. Usulan Meja Makan

Tabel 15. Concept Scoring Meja Makan

\begin{tabular}{|c|c|c|c|c||}
\hline \multirow{2}{*}{ No } & \multirow{2}{*}{ Kriteria Penilaian } & \multicolumn{3}{|c||}{ Rancangan } \\
\cline { 3 - 5 } & & Alternatif 1 & Alternatif 2 & Alternatif 3 \\
\cline { 3 - 5 } & Rating & Rating & Rating \\
\hline 1 & Kepraktisan & 1 & 3 & 2 \\
\hline 2 & Kesesuaian data & 2 & 1 & 3 \\
\hline \multicolumn{2}{|c|}{ Total Nilai } & 3 & 4 & 5 \\
\hline \multicolumn{2}{|c|}{ Peringkat } & 3 & 2 & 1 \\
\hline \hline
\end{tabular}

\subsubsection{Safety Belt}

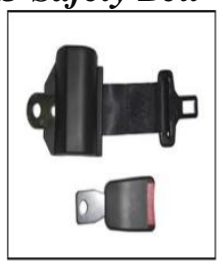

\begin{tabular}{|c|c|}
\hline Wima & Pin \\
\hline Bablex & 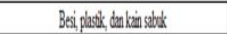 \\
\hline Rapustas & larag \\
\hline Fussi & 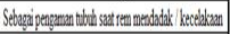 \\
\hline \multicolumn{2}{|r|}{ Keturnąan } \\
\hline \multicolumn{2}{|l|}{ Hxameninitus } \\
\hline \multicolumn{2}{|c|}{ 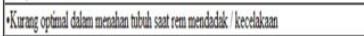 } \\
\hline \multicolumn{2}{|c|}{ 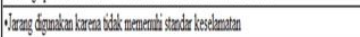 } \\
\hline
\end{tabular}
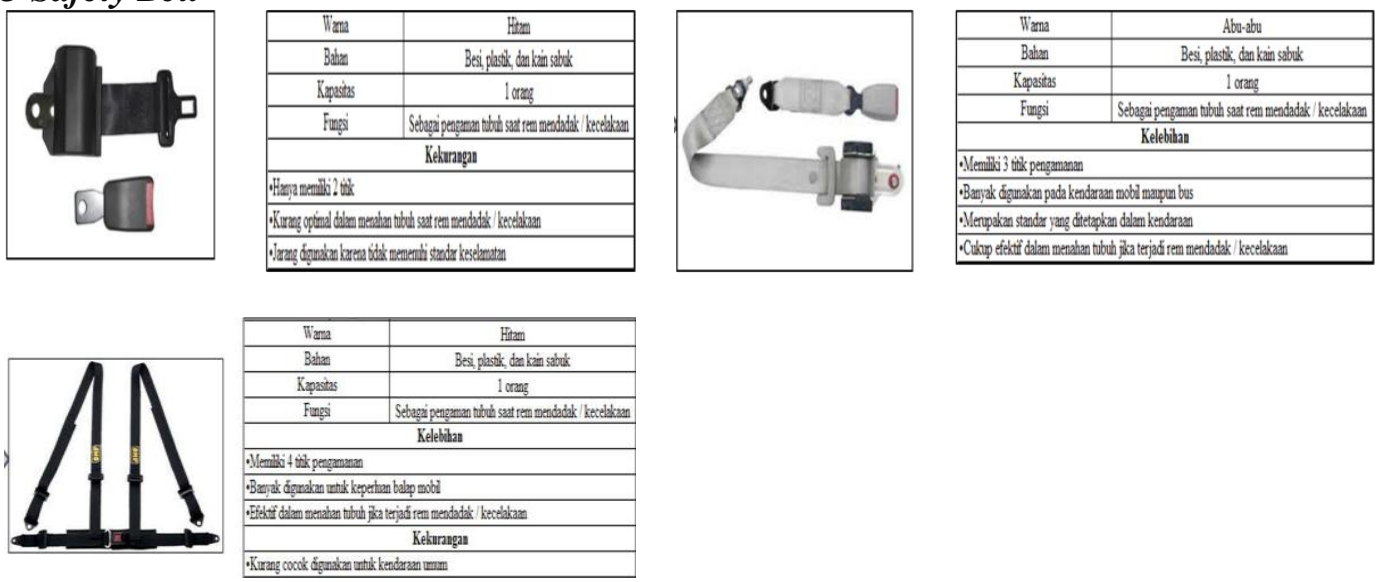

Gambar 19. Usulan Safety Belt 
JOURNAL OF INTEGRATED S YSTEM VOL 1. NO. 2, DES EMB ER 2018: 193-215

Tabel 16. Concept Scoring Safety Belt

\begin{tabular}{|c|c|c|c|c|}
\hline \multirow{2}{*}{ No } & \multirow{2}{*}{ Kriteria Penilaian } & \multicolumn{3}{|c|}{ Rancangan } \\
\cline { 3 - 5 } & & Alternatif 1 & Alternatif 2 & Alternatif 3 \\
\cline { 3 - 5 } & Rating & Rating & Rating \\
\hline 1 & Kepraktisan & 3 & 2 & 1 \\
\hline 2 & Keamanan & 1 & 2 & 3 \\
\hline 3 & Keleluasaan & 2 & 3 & 1 \\
\hline & Total Nilai & 6 & 7 & 5 \\
\hline & Peringkat & 2 & 1 & 3 \\
\hline
\end{tabular}

\subsubsection{Magazine Pocket}
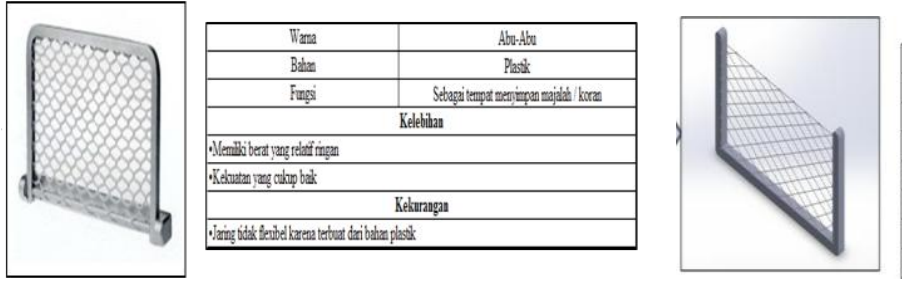

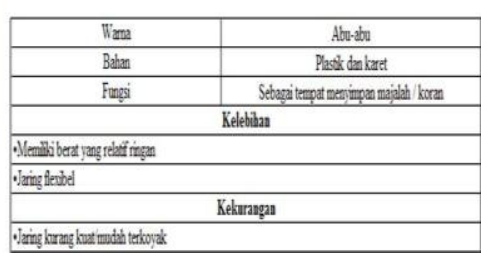
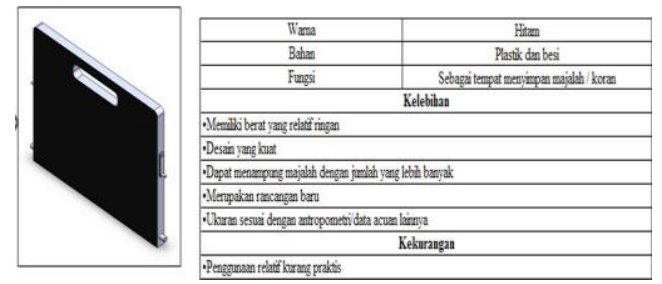

Gambar 20. Usulan Magazine Pocket

Tabel 17. Concept Scoring Magazine Pocket

\begin{tabular}{|c|c|c|c|c|}
\hline \multirow{2}{*}{ No } & \multirow{3}{*}{ Kriteria Penilaian } & \multicolumn{3}{|c|}{ Rancangan } \\
\cline { 3 - 5 } & & Alternatif 1 & Alternatif 2 & Alternatif 3 \\
\cline { 3 - 5 } & Rating & Rating & Rating \\
\hline 1 & Kapasitas & 1 & 2 & 3 \\
\hline 2 & Kepraktisan & 2 & 3 & 1 \\
\hline 3 & Kekuatan & 2 & 1 & 3 \\
\hline 4 & Keamanan & 1 & 2 & 3 \\
\hline & Total Nilai & 6 & 8 & 10 \\
\hline & Peringkat & 2 & 3 & 1 \\
\hline
\end{tabular}

\subsubsection{Glass/Bottle Pocket}
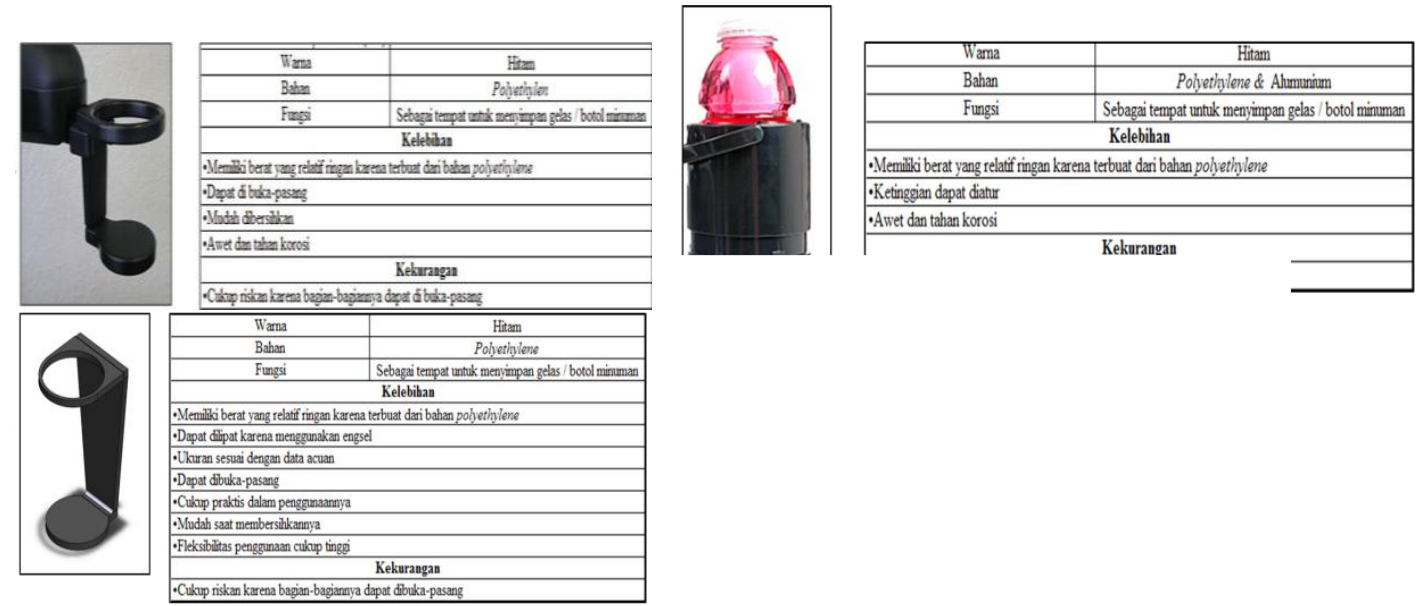

Gambar 21. Usulan Glass/Bottle Pocket 
ANALIS IS DAN PERANCANGAN KURS I PENUMPANG B IS PARIWISATA (Wawan Y., dkk)

Tabel 18. Concept Scoring Glass/Bottle Pocket

\begin{tabular}{|c|c|c|c|c||}
\hline \multirow{2}{*}{ No } & \multirow{2}{*}{ Kriteria Penilaian } & \multicolumn{3}{|c||}{ Rancangan } \\
\cline { 3 - 5 } & & Alternatif 1 & Alternatif 2 & Alternatif 3 \\
\cline { 3 - 5 } & Rating & Rating & Rating \\
\hline 1 & Flexibilitas & 2 & 1 & 3 \\
\hline 2 & Perawatan & 2 & 1 & 3 \\
\hline 3 & Kesesuaian data & 1 & 2 & 3 \\
\hline & Total Nilai & 5 & 4 & 9 \\
\hline & Peringkat & 2 & 3 & 1 \\
\hline
\end{tabular}

\subsubsection{Footrest}
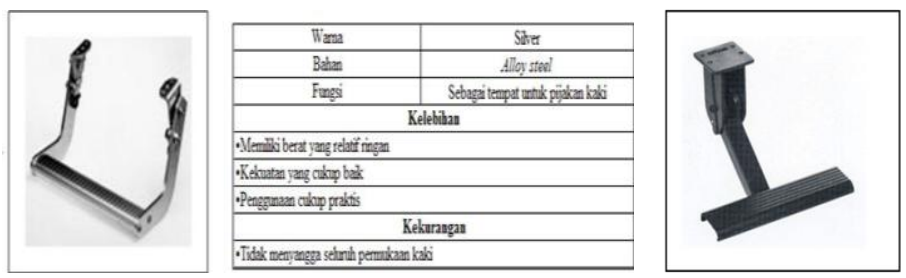

\begin{tabular}{|c|c|}
\hline Wama & Hitam \\
\hline Bahan & Alloy steel \\
\hline Fungsi & Sebagai tempat untuk pijakan kak \\
\hline \multicolumn{2}{|c|}{ Kelebihan } \\
\hline \multicolumn{2}{|c|}{-Memiliki berat yang relatif ringan } \\
\hline \multicolumn{2}{|c|}{-Kekuatan yang culup balk } \\
\hline \multicolumn{2}{|l|}{ - Penggunaan cukup praktis } \\
\hline \multicolumn{2}{|c|}{ Kekurangan } \\
\hline -Tidak menyangga selurn: & \\
\hline
\end{tabular}
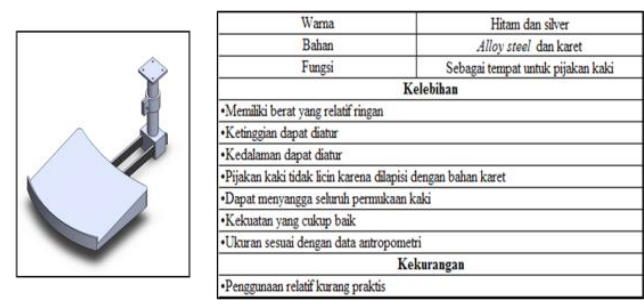

Gambar 22. Usulan Footrest

Tabel 19. Concept Scoring Footrest

\begin{tabular}{|c|c|c|c|c|}
\hline \multirow{2}{*}{ No } & \multirow{2}{*}{ Kriteria Penilaian } & \multicolumn{3}{|c|}{ Rancangan } \\
\cline { 3 - 5 } & & Alternatif 1 & Alternatif 2 & Alternatif 3 \\
\cline { 3 - 5 } & Rating & Rating & Rating \\
\hline 1 & Flexibilitas & 1 & 2 & 3 \\
\hline 2 & Kesesuaian data & 1 & 2 & 3 \\
\hline & Total Nilai & 2 & 4 & 6 \\
\hline \multicolumn{2}{|c|}{ Peringkat } & 3 & 2 & 1 \\
\hline
\end{tabular}

\subsubsection{Rel}
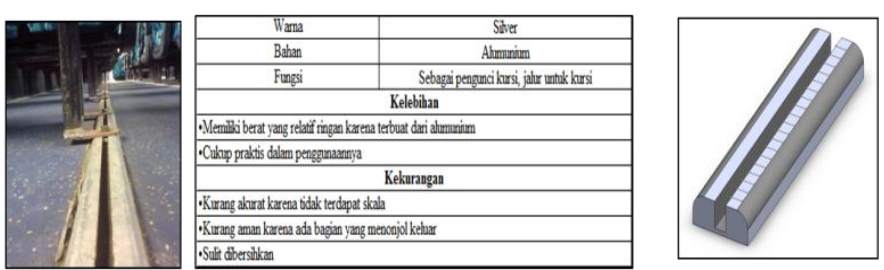

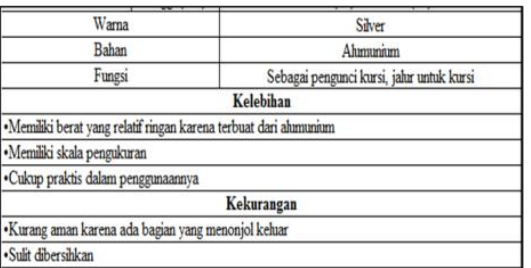
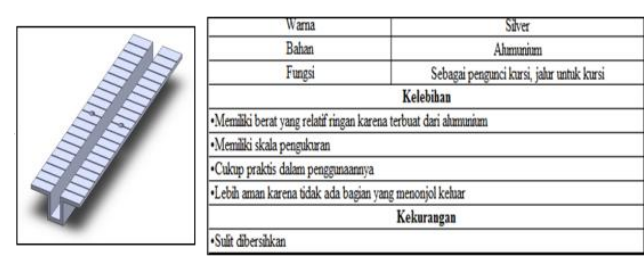

Gambar 23. Usulan Re1 
JOURNAL OF INTEGRATED S YSTEM VOL 1. NO. 2, DES EMB ER 2018: 193-215

Tabel 20. Concept Scoring Rel

\begin{tabular}{|c|c|c|c|c|}
\hline \multirow{2}{*}{ No } & \multirow{2}{*}{ Kriteria Penilaian } & \multicolumn{3}{|c|}{ Rancangan } \\
\cline { 3 - 5 } & & Alternatif 1 & Alternatif 2 & Alternatif 3 \\
\cline { 3 - 5 } & Rating & Rating & Rating \\
\hline 1 & Keamanan & 1 & 2 & 3 \\
\hline 2 & Kepraktisan & 1 & 2 & 3 \\
\hline & Total Nilai & 2 & 4 & 6 \\
\hline & Peringkat & 3 & 2 & 1 \\
\hline
\end{tabular}

\subsubsection{Kursi Penumpang Bis}
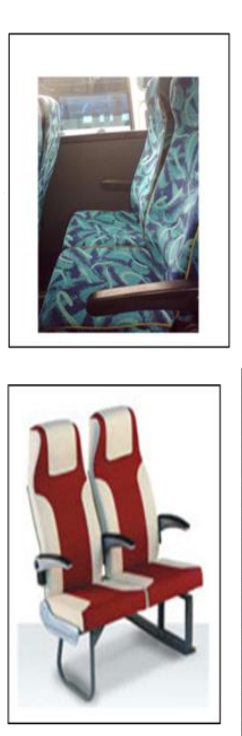

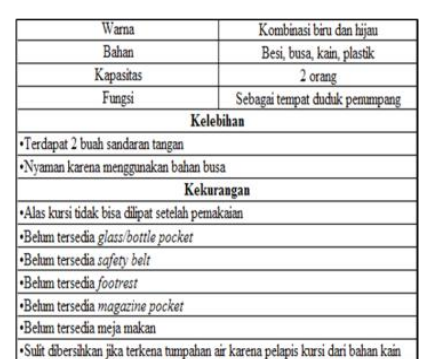

-Sulit dibersibkan jka terkena tumpahan ait karena pelapis kursi dari bahan kain

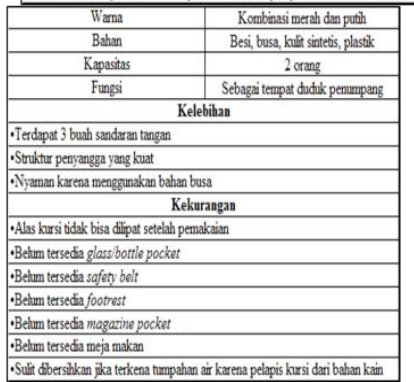

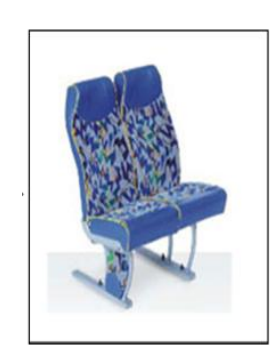

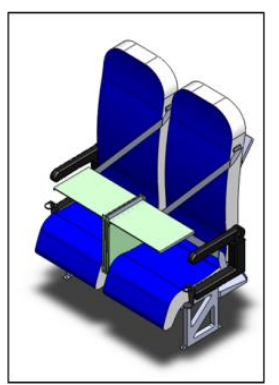

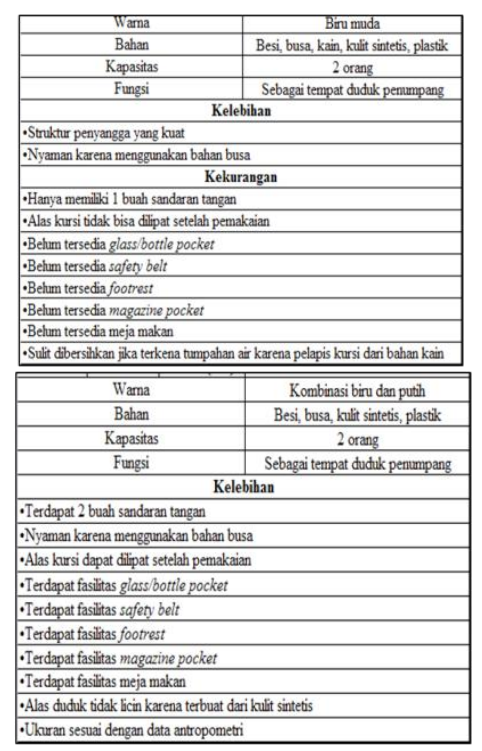

- Uhuran sesuai dengan data antropometri

Gambar 24. Usulan Kursi Penumpang Bis

Tabel 21. Concept Scoring Kursi Penumpang Bis

\begin{tabular}{|c|c|c|c|c|c|}
\hline \multirow{3}{*}{ No } & \multirow{3}{*}{ Kriteria Penilaian } & \multicolumn{4}{|c|}{ Rancangan } \\
\hline & & Alternatif 1 & Alternatif 2 & Alternatif 3 & Alternatif 4 \\
\hline & & Rating & Rating & Rating & Rating \\
\hline 1 & Keamanan & 1 & 2 & 3 & 4 \\
\hline 2 & Kepraktisan & 2 & 3 & 1 & 4 \\
\hline 3 & Perawatan & 1 & 2 & 3 & 4 \\
\hline 4 & Kesesuaian data & 1 & 2 & 3 & 4 \\
\hline 5 & Fasilitas & 1 & 2 & 3 & 4 \\
\hline & Total Nilai & 6 & 11 & 13 & 20 \\
\hline & Peringkat & 4 & 3 & 2 & 1 \\
\hline
\end{tabular}

\subsection{Pe rancangan Lingkungan Fisik $B$ is}

\subsubsection{Temperatur dan Ke lembaban}

Dikarenakan temperatur dan kelembaban berada dalam zona nyaman, maka dari itu tidak diperlukan perbaikan atau perancangan. 


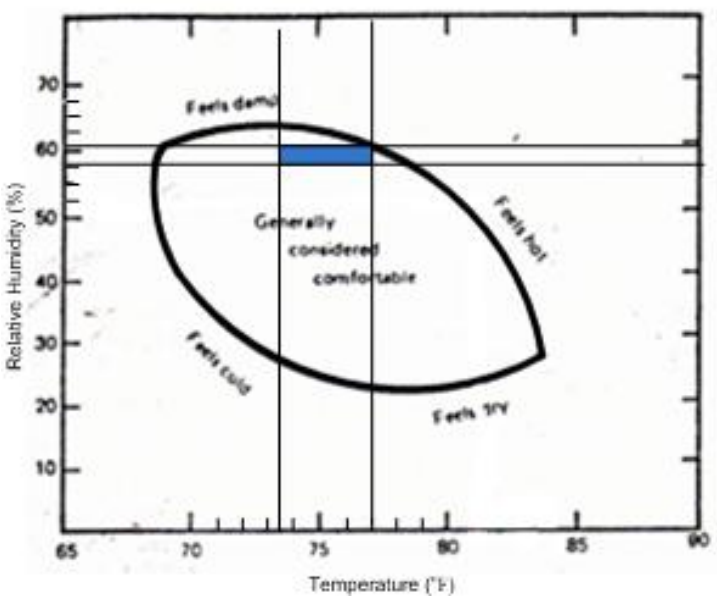

Gambar 25. Thermal Comfort Zone
Berdasarkan Handbook of Ergonomic and Human Factor Tables temperatur yang ideal adalah antara $19^{\circ} \mathrm{C}-26^{\circ} \mathrm{C}$ dengan kelembaban antara $20 \%-85 \%$

\subsubsection{Kebisingan}

Diusulkan untuk menggunakan karpet karet dan/atau glasswoll di dalam ruangan mesin untuk meredam kebisingan yang ditimbulkan dari suara mesin bis.
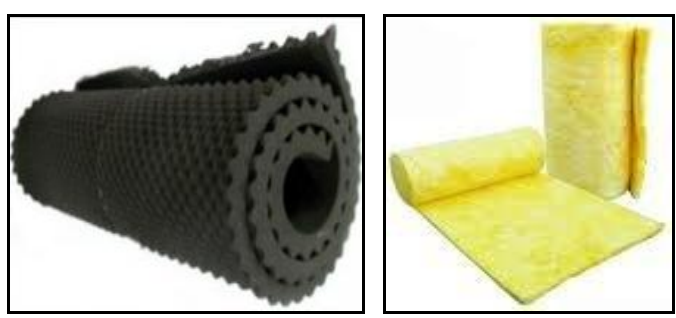

Gambar 26. Karpet Karet dan Glasswoll
Berdasarkan Klasifikasi kebis ingan Furrer tingkat kebisingan yang ideal adalah antara $30 \mathrm{~dB}-40 \mathrm{~dB}$

\subsubsection{Sirkulasi Udara}

Sirkulasi udara sudah cukup baik karena aliran udara tersebar merata karena di dalam kabin bis terdapat blower yang berfungsi mengalirkan udara ke seluruh bagian kabin bis. Maka dari itu tidak diperlukan perbaikan untuk sirkulasi udara di dalam kabin bis karena sudah cukup baik. Hal ini terbukti dengan temperatur dan kelembaban di dalam kabin bis yang masuk zona nyaman di seluruh bagiannya.

\subsubsection{Pencahayaan}

Usulan untuk perbaikan tingkat pencahayaan ini adalah dengan menambahkan beberapa buah lampu neon 40 watt di sepanjang kabin bis untuk menambah tingkat pencahayaan sehingga menjadi lebih baik dan sesuai dengan batasan atau ketentuan yang ditetapkan.

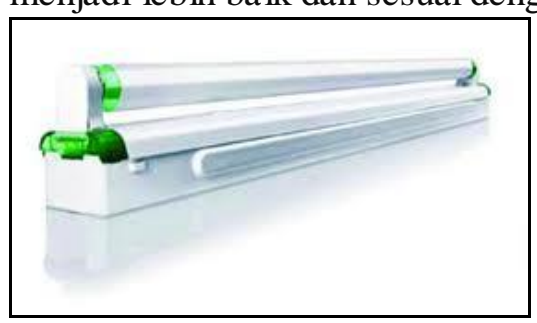

Berdasarkan Handbook of Ergonomic and Human Factor Tables pencahayaan minimal untuk pekerjaan adalah 75 lux.

Gambar 27. Lampu Neon Panjang

\subsection{Pe rancangan Kesehatan dan Keselamatan Kerja}

\subsubsection{Kesehatan Ke rja}

- Menambahkan tempat sampah sebanyak 2 buah (di bagian depan dan belakang kabin bis). Dengan menambahkan tempat sampah di dalam kabin bis maka dapat mencegah kondisi lingkungan yang kotor akibat sampah dari penumpang. 


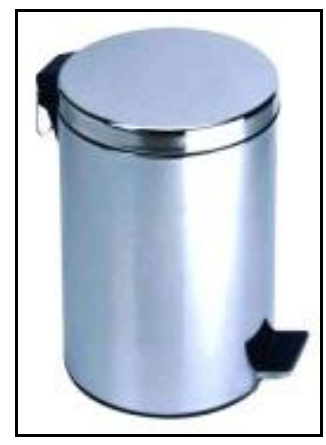

\begin{tabular}{|c|c|c|}
\hline \multirow{2}{*}{ Jenis } & Dimensi & Tempat Sampah \\
\hline \multirow{2}{*}{ Tempat Sampah } & Tinggi (mm) & 400 \\
\cline { 2 - 3 } & Diameter (mm) & Silver \\
\hline Warna & Stainless Steel \\
\hline Bahan & Sebagai tempat menampung sampah \\
\hline \multicolumn{2}{|c|}{ Kungsi } \\
\hline \multicolumn{2}{|c|}{ Kelebihan } \\
\hline - Memiliki pedal \\
\hline - Tidak membutuhkan banyak tempat \\
\hline - Meningkatkan kebersihan kabin bis \\
\hline \multicolumn{2}{|c|}{ Kekurangan } \\
\hline -Lebih berat dibandingkan dengan bahan plastik \\
\hline
\end{tabular}

Gambar 28. Tempat Sampah

- Menambahkan stiker peringatan dilarang merokok di dalam kabin bis. Dengan memberikan stiker peringatan dilarang merokok di dalam kabin bis, maka kebersihan udara di dalam kabin pun akan terjaga karena tidak akan ada penumpang yang merokok.

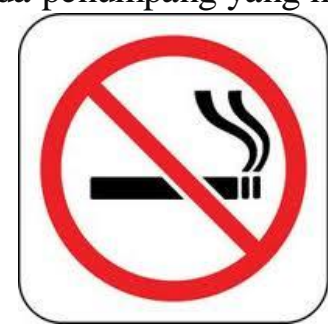

Gambar 29. No Smoking Sign

\subsubsection{Keselamatan Kerja}

- Menyediakan fire extinguisher, sehingga ketika terjadi percikan api di dalam kabin bis dapat dicegah dengan menyemprotkan fire extinguisher pada sumber api tersebut. Selain itu melakukan training pada supir maupun awak bis mengenai cara menggunakan alat tersebut. Fire extinguisher ini akan ditempatkan di bagian depan dekat dengan dashboard dan belakang kabin yaitu pada tempat penyimpanan barang agar mudah terlihat jika suatu waktu akan dipergunakan, dengan jumlah 2 buah.
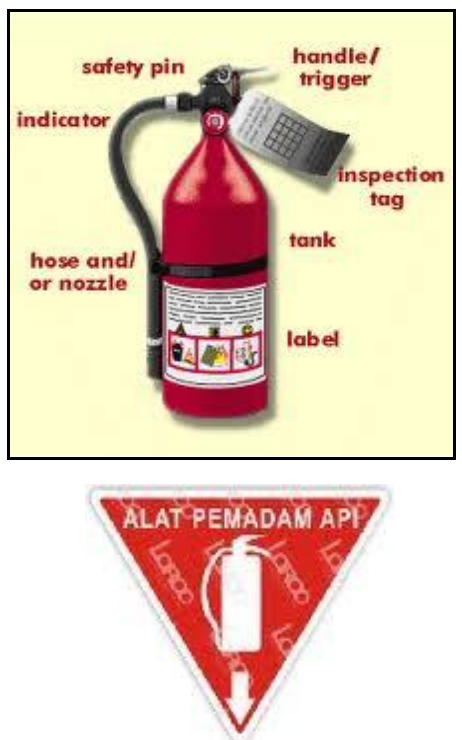

\begin{tabular}{|l|c|c|}
\hline \multirow{2}{*}{ Jenis } & Dimensi & Fire Extinguisher \\
\hline \multirow{3}{*}{ Fire Extinguisher } & Tinggi (mm) & 480 \\
\cline { 2 - 3 } & Lebar (mm) & 220 \\
\cline { 2 - 3 } & Diameter (mm) & 130 \\
\hline \multicolumn{2}{|c|}{ Warna } & Merah \\
\hline \multicolumn{2}{|c|}{ Jenis } & Dry Powder \\
\hline \multicolumn{2}{|c|}{ Fungsi } & Sebagai alat pemadam api \\
\hline \multicolumn{2}{|c|}{ Kapasitas } \\
\hline \multicolumn{2}{|c|}{ Kelebihan } \\
\hline -Efektif untuk jenis kebakaran kelas A, B, dan C \\
\hline -Efektif untuk bahan elektrik, kayu, kertas, kain, bahan cair \\
\hline
\end{tabular}


ANALIS IS DAN PERANCANGAN KURS I PENUMPANG B IS PARIW ISATA (Wawan Y., dkk)

- Menyediakan kotak P3K, sehingga ketika terjadi kecelakaan di dalam kabin bis dapat langsung ditanggulangi sementara dengan adanya kotak P3K. Pemilihan kotak bentuk 1 adalah berdasarkan kriteria yang ditentukan untuk jumlah orang antara 25 - 100 orang.
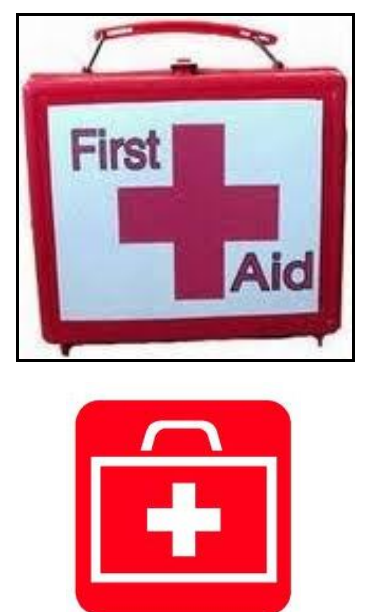

\begin{tabular}{|l|l|}
\hline$\cdot 10$ gram kapas putih & $\cdot 10$ buah plester cepat (mis: Tensoplast, dil) \\
\hline-1 rol pembalut gulung lebar $2,5 \mathrm{~cm}$ & $\cdot 1$ buah gunting \\
\hline$\cdot 1$ rol pembalut gulung lebar $5 \mathrm{~cm}$ & $\cdot 1$ buku catatan \\
\hline-1 pembalut segitiga (mitella) & $\cdot 1$ buku pedoman $\mathrm{P} 3 \mathrm{~K}$ \\
\hline-1 pembalut cepat steril/snelverband & $\cdot 1$ daftar isi kotak $\mathrm{P} 3 \mathrm{~K}$ \\
\hline-10 buah kassa steril ukuran $5 \times 5 \mathrm{~cm}$ & $\cdot$ Obat merah \\
\hline$\cdot 1$ rol plester lebar $2,5 \mathrm{~cm}$ & $\cdot$ Soda kue \\
\hline- Obat pelawan rasa sakit (mis: Antalgin, dil) & $\cdot$ Obat anti alergi \\
\hline - Obat sakit perut (mis: Paverin, dil) & $\cdot$ Obat tetes mata \\
\hline- Norit & $\cdot$ Obat gosok \\
\hline
\end{tabular}

Gambar 31. Kotak P3K \& Sign

- Menyediakan 2 buah emergency hammer, alat ini berfungsi untuk memecahkan kaca bis jika terjadi suatu kecelakaan atau kebakaran di dalam kabin bis, sehingga penumpang dapat keluar melalui kaca tersebut. Alat ini diletakan pada dinding di samping kiri dan kanan kabin bis.

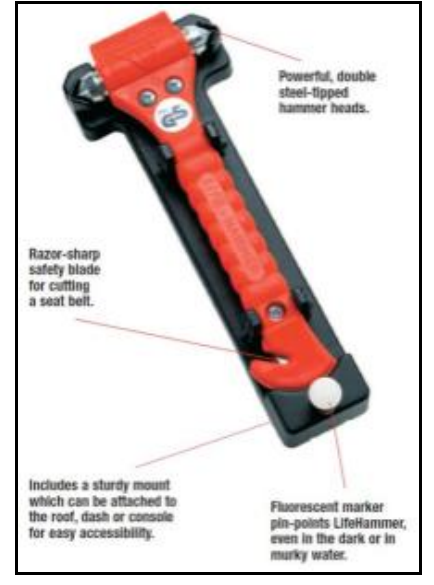

Emergency hammer

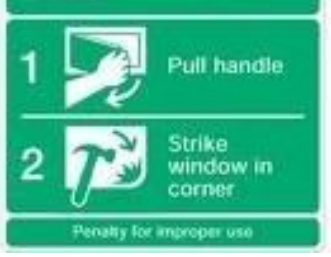

\begin{tabular}{|l|c|c|}
\hline \multirow{2}{*}{ Jenis } & Dimensi & Emergency Hammer \\
\hline \multirow{3}{*}{ Emergency Hammer } & Tinggi (mm) & 195.58 \\
\cline { 2 - 3 } & Lebar (mm) & 71.12 \\
\cline { 2 - 3 } & Panjang (mm) & 35.56 \\
\hline Warna & Merah \\
\hline Bahan & Besi dan plastik \\
\hline \multicolumn{2}{|c|}{ Fungsi } \\
\hline \multicolumn{2}{|c|}{ Kelebihan } \\
\hline - Memiliki 2 buah kepala palu alat pemecah kaca \\
\hline -Terdapat pisau untuk memotong safety belt \\
\hline -Terdapat tanda yang dapat menyala di kegelapan \\
\hline -Dilengkapi dengan wadah penyimpanan \\
\hline
\end{tabular}

Gambar 32. Emergency Hammer \& Sign 


\section{JOURNAL OF INTEGRATED S YSTEM VOL 1. NO.2, DES EMB ER 2018: 193-215}

- Menambahkan lampu pada anak tangga, untuk mempermudah penumpang di malam hari saat akan menaiki tangga sehingga kemungkinan terjatuh dapat diminimalis ir.

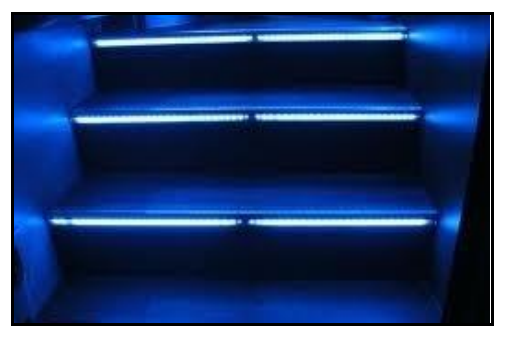

Gambar 33. Lampu Tangga

6.4 Pe rancangan Layout $B$ is

6.4.1 Usulan Layout B is 1 (Ekonomis)

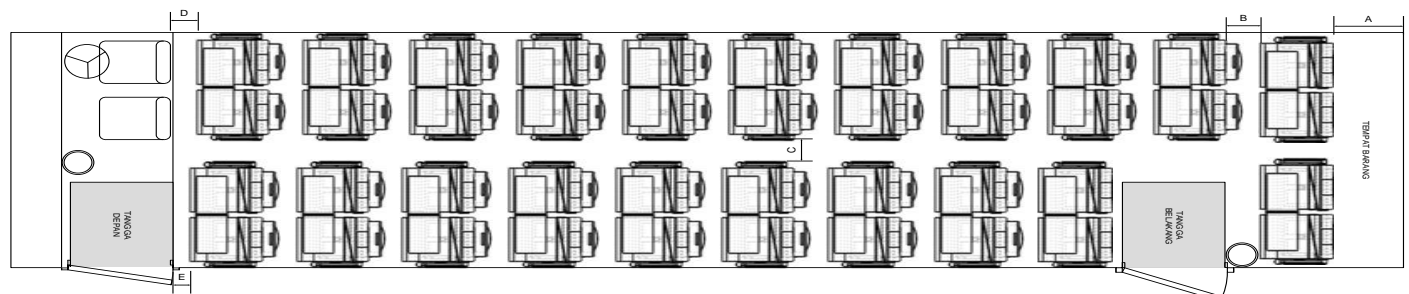

Gambar 34. Layout Bis 1

\subsubsection{Usulan Layout B is 2 (Ekonomis)}

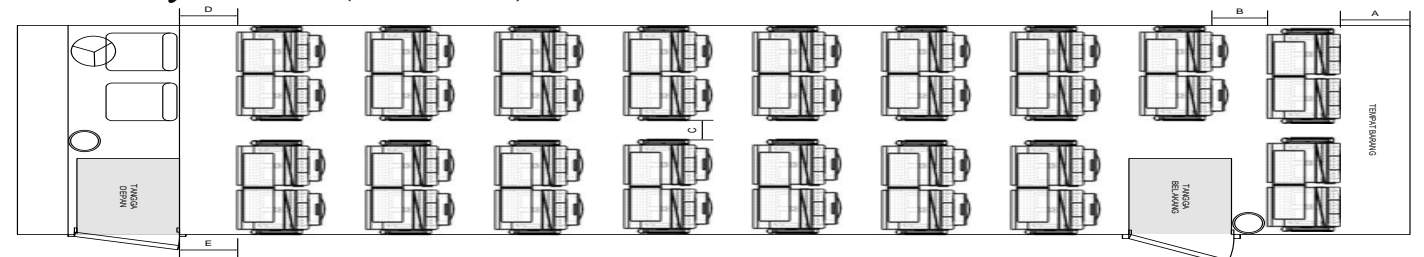

Gambar 35. Layout Bis 2

\subsubsection{Usulan Layout B is 3 (Ekonomis)}

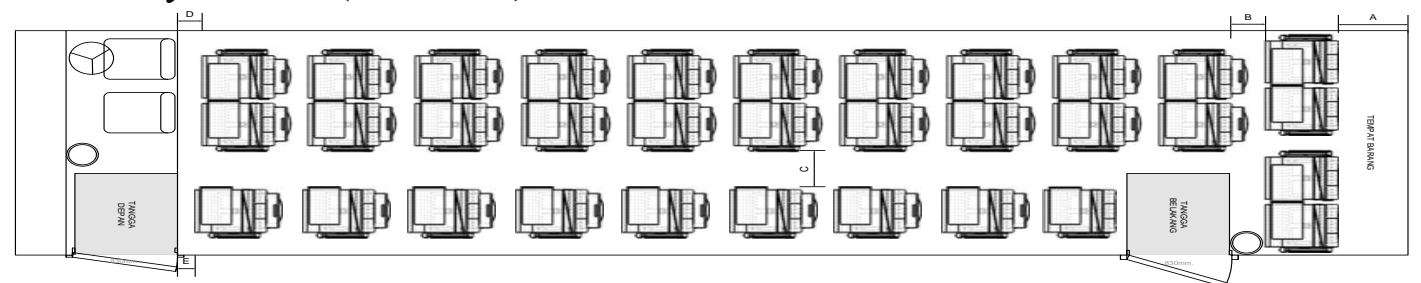

Gambar 36. Layout Bis 3

\subsubsection{Usulan Layout B is 4 (Ergonomis)}

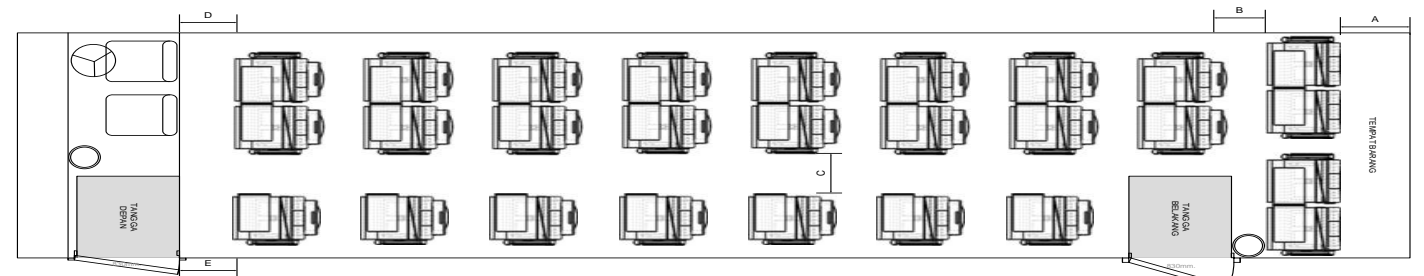

Gambar 37. Layout Bis 4 


\subsubsection{Usulan Layout B is 5 (Ergonomis)}

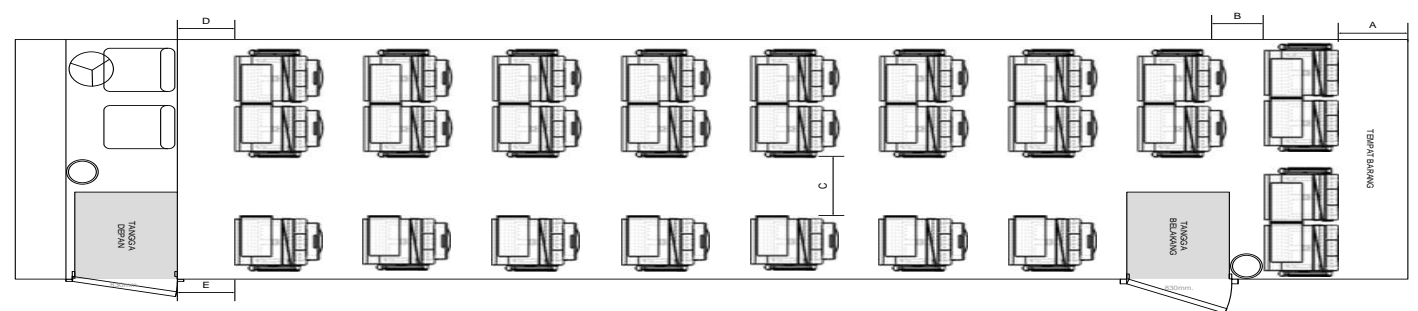

Gambar 38. Layout Bis 5

\subsubsection{Usulan Layout B is 6 (Ergonomis)}

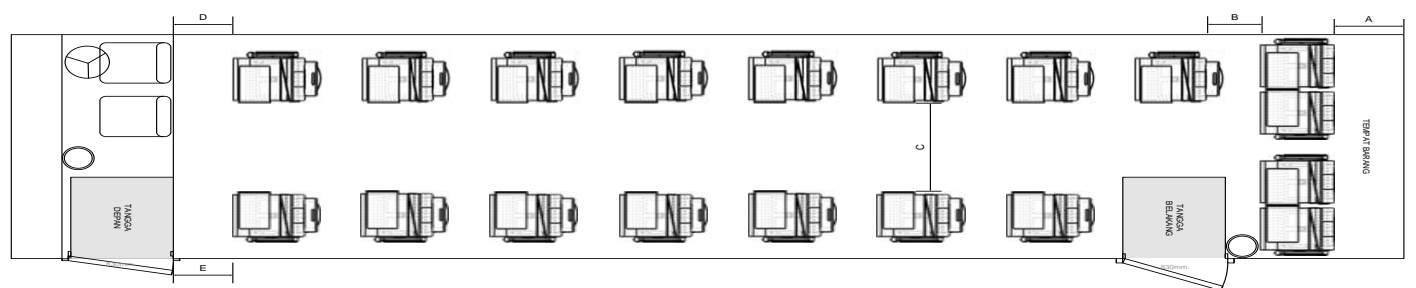

Gambar 39. Layout Bis 6

Tabel 22. Rangkuman Alternatif Layout Bis Usulan

\begin{tabular}{|c|l|c|c|c|c|c|c||}
\hline \multirow{2}{*}{ Layout } & \multirow{2}{*}{ Group } & \multicolumn{3}{|c|}{ Formasi Kursi } & \multirow{2}{*}{$\begin{array}{c}\text { Jumlah Kursi } \\
\text { (Unit) }\end{array}$} & $\begin{array}{c}\text { Lebar Gang } \\
(\mathrm{mm})\end{array}$ & $\begin{array}{c}\text { Jarak Antar Kursi } \\
(\mathrm{mm})\end{array}$ \\
\cline { 3 - 5 } & & Kanan & Kiri & Belakang & 42 & 190 & 268.8 \\
\hline 1 & Ekonomis & 2 & 2 & 4 & 34 & 190 & 455 \\
\hline 2 & Ekonomis & 2 & 2 & 4 & 33 & 392 & 268.8 \\
\hline 3 & Ekonomis & 2 & 1 & 4 & 27 & 392 & 455 \\
\hline 4 & Ergonomis & 2 & 1 & 4 & 27 & 610 & 455 \\
\hline 5 & Ergonomis & 2 & 1 & 4 & 19 & 920 & 455 \\
\hline 6 & Ergonomis & 1 & 1 & 4 & 19 & 45 \\
\hline \hline
\end{tabular}

\section{Kesimpulan dan Saran}

\subsection{Kesimpulan}

- Fasilitas fisik utama yang menjadi usulan adalah sebagai berikut:

- Sandaran tangan

Berdasarkan kriteria-kriteria penilaian seperti flexibilitas, kepraktisan, perawatan, kesesuaian data dengan antropometri, dan estetika maka sandaran tangan alternatif 4 terpilih untuk diaplikasikan.

- Meja makan

Berdasarkan kriteria-kriteria penilaian seperti kepraktisan, kesesuaian data dengan antropometri, dan estetika maka meja makan alternatif 3 terpilih untuk diaplikasikan.

- Safety belt

Berdasarkan kriteria-kriteria penilaian seperti kepraktisan, kesesuaian data dengan antropometri, keamanan, dan keleluasaan, maka safety belt alternatif 2 terpilih untuk diaplikasikan.

- Magazine pocket

Berdasarkan kriteria-kriteria penilaian seperti kapasitas, kepraktisan, kekuatan, keamanan, dan estetika maka magazine pocket alternatif 3 terpilih untuk diaplikasikan.

- Glass / bottle pocket

Berdasarkan kriteria-kriteria penilaian seperti flexibilitas, perawatan, kesesuaian dengan data antropometri, dan estetika maka glass / bottle pocket alternatif 3 terpilih untuk diaplikasikan.

- Footrest

Berdasarkan kriteria-kriteria penilaian seperti flexibilitas, kesesuaian dengan data antropometri, dan estetika maka footrest alternatif 3 terpilih untuk diaplikasikan. 
- Rel

Berdasarkan kriteria-kriteria penilaian seperti keamanan, kepraktisan, dan estetika maka rel alternatif 3 terpilih untuk diaplikasikan dengan spesifikasi:

- Kursi penumpang bis

Berdasarkan kriteria-kriteria penilaian seperti keamanan, kepraktisan, perawatan, kesesuaian dengan data antropometri, fasilitas, dan estetika maka kursi penumpang bis alternatif 4 terpilih untuk diaplikasikan.

- Perancangan lingkungan fisik di dalam kabin bis yang ergonomis

1. Temperatur dan Kelembaban

2. Untuk temperatur dan kelembaban yang ada di dalam kabin bis tidak diperlukan perbaikan, karena masuk ke dalam green zone atau zona nyaman.

3. Kebisingan

4. Untuk kebisingan di dalam kabin bis diperlukan perbaikan dengan memasang glasswoll atau/dan karpet karet di bagian belakang karena terdapat ruangan penyimpanan mesin bis.

5. Sirkulasi Udara

6. Untuk sirkulasi udara di dalam kabin bis sudah cukup baik karena terdapat blower dan exhaust fan sehingga penyebaran lebih merata, maka dari itu tidak diperlukan perbaikan.

7. Pencahayaan

8. Untuk pencahayaan di dalam kabin bis diperlukan perbaikan dengan menambahkan beberapa buah lampu neon panjang 40 watt di sepanjang kabin bis untuk mendapatkan pencahayaan yang lebih baik.

- Perancangan Kesehatan dan Keselamatan bis

1. Untuk kondisi kebersihan di dalam kabin bis belum terdapat tempat sampah yang menampung sampah-sampah di dalam kabin.

2. Belum tersedianya PPE (Personel Protective Equipment) di dalam kabin bis untuk mencegah dampak kecelakaan yang mungkin terjadi.

3. Belum tersedianya fasilitas keselamatan seperti fire extinguisher di dalam kabin bis untuk mencegah dan menanggulangi kebakaran.

4. Belum tersedianya fasilitas keselamatan seperti kotak P3K di dalam kabin bis untuk menaggulangi kecelakaan.

5. Belum tersedianya fasilitas keselamatan seperti emergency hammer di dalam kabin bis untuk mencegah dan menanggulangi jika terjadi kecelakaan.

6. Belum tersedianya lampu pada tangga bis, sehingga dapat meningkatkan resiko terjatuh pada penumpang.

- Perancangan layout bis

Pada perancangan layout bis ini, diusulkan 6 buah alternatif layout yang dapat digunakan dengan rancangan kursi penumpang yang baru. Namun layout tersebut masih dapat disesuaikan lagi dengan keinginan dari konsumen (fleksibel). Untuk grup ekonomis pertimbangan yang dilakukan berdasarkan jumlah kursi yang digunakan mendekati kondisi aktual. Berikut ini adalah rangkuman dari lima alternatif yang diusulkan :

Tabel 23. Rangkuman Alternatif Layout Bis Usulan

\begin{tabular}{|c|l|c|c|c|c|c|c||}
\hline \multirow{2}{*}{ Layout } & \multirow{2}{*}{ Group } & \multicolumn{3}{|c|}{ Formasi Kursi } & \multirow{2}{*}{$\begin{array}{c}\text { Jumlah Kursi } \\
\text { (Unit) }\end{array}$} & $\begin{array}{c}\text { Lebar Gang } \\
(\mathrm{mm})\end{array}$ & $\begin{array}{c}\text { Jarak Antar Kursi } \\
(\mathrm{mm})\end{array}$ \\
\cline { 3 - 5 } & & Kanan & Kiri & Belakang & 42 & 190 & 268.8 \\
\hline 1 & Ekonomis & 2 & 2 & 4 & 4 & 190 & 455 \\
\hline 2 & Ekonomis & 2 & 2 & 4 & 34 & 392 & 268.8 \\
\hline 3 & Ekonomis & 2 & 1 & 4 & 27 & 392 & 455 \\
\hline 5 & Ergonomis & 2 & 1 & 4 & 27 & 610 & 455 \\
\hline 6 & Ergonomis & 2 & 1 & 4 & 19 & 920 & 455 \\
\hline \hline
\end{tabular}




\subsection{Saran}

- Saran yang diberikan untuk fasilitas fisik bis antara lain:

- Untuk sandaran tangan sebaiknya digunakan sandaran tangan yang memiliki sifat adjustable, sehingga ketinggiannya dapat diatur dan juga untuk dimensinya disesuaikan dengan data antropometri.

- Perlu ditambahkan fasilitas meja makan pada kursi penumpang karena akan meningkatkan nilai dari bis tersebut, juga meningkatkan useability dan flexibilitas. Selain itu dimensi dari meja makan disesuaikan dengan data antropometri.

- Perlu ditambahkan fasilitas safety belt pada kursi penumpang karena akan meminimalisir dampak dari kecelakaan yang mungkin terjadi dan juga meningkatkan keselamatan penumpang. Se lain itu letak dari safety belt disesuaikan dengan data antropometri.

- Dimensi dari magazine pocket disesuaikan dengan data acuan majalah dan letaknya disesuaikan dengan data antropometri.

- Perlu ditambahkan fasilitas glass / bottle pocket untuk meningkatkan nilai dari bis, meningkatkan kenyamanan penumpang dan juga dimensinya disesuaikan dengan data antropometri.

- Perlu ditambahkan fasilitas footrest untuk meningkatkan nilai dari bis, meningkatkan kenyamanan penumpang, dan dimens inya disesuaikan dengan data antropometri.

- Desain rel sebaiknya tidak terlalu menonjol keluar karena dapat membahayakan penumpang, selain itu perlu ditambahkan skala pada rel untuk mempermudah saat pemindahan kursi.

- Kursi penumpang harus sesuai dengan data antropometri dan didukung dengan fasilitas pendukung yang cukup memadai untuk meningkatkan nilai dari bis itu sendiri.

- Saran yang diberikan untuk lingkungan fisik bis antara lain:

- Perlu dilakukan perbaikan terhadap tingkat kebisingan di dalam bis dengan menambahkan karpet karet atau glasswoll di bagian belakang bis.

- Perlu dilakukan perbaikan terhadap tingkat pencahayaan di da lam bis dengan menambahkan beberapa buah lampu neon panjang 40 watt di sepanjang kabin bis.

- Saran yang diberikan untuk kesehatan dan keselamatan bis antara lain:

- Perlu ditambahkan tempat sampah untuk menampung sampah-sampah yang ada di dalam kabin bis, sehingga kebersihan kabin dapat terjaga.

- Perlu ditambahkan tanda dilarang merokok di dalam kabin bis, agar tidak ada penumpang yang merokok dan dapat mengganggu kenyamanan udara di dalam kabin.

- Perlu ditambahkan PPE (Personal Protective Equipment) di dalam kabin bis untuk mencegah dampak yang mungkin terjadi saat kecelakaan.

- Perlu ditambahkan fasilitas fire extinguisher sebanyak 2 buah di dalam kabin bis untuk mencegah dan menanggulangi kebakaran yang terjadi di kabin.

- Perlu ditambahkan fasilitas kotak P3K di dalam kabin bis untuk menanggulangi kecelakaan yang terjadi di kabin.

- Perlu ditambahkan fasilitas emergency hammer sebanyak 2 buah di dalam kabin bis untuk mencegah dan menanggulangi jika terjadi kecelakaan yang terjadi di kabin dan penumpang terjebak di dalam.

- Perlu ditambahkan lampu pada tangga untuk membantu penumpang saat naik atau turun tangga, juga untuk meminimalis ir kejadian terjatuh pada penumpang.

- Saran yang diberikan untuk layout bis

Menggunakan salah satu alternatif layout bis usulan dengan rancangan kursi penumpang bis yang baru. 
JOURNAL OF INTEGRATED S YSTEM VOL 1. NO. 2, DES EMB ER 2018: 193-215

\section{Daftar Pus taka}

Nurmianto, Eko. Ir., M.Eng.Sc., DERT.; "Ergonomi : Konsep Dasar dan Aplikasinya, Edisi Kedua”, Penerbit Guna Widya, Surabaya, 2004.

Sugiyono, Prof., DR.; “Metode Penelitian Administrasi Dilengkapi dengan Metode R\&D”, CV Alfabeta, Bandung, 2008.

Sutalaksana, Iftikar Z.; Anggawisastra, Ruhana.; Tjakraatmadja, John H.; “ Teknik Perancangan Sistem Kerja ”, Dept Teknik Industri ITB, Bandung, 1979.

Tim Asisten Laboratorium APK \& E Fakultas Teknik Jurusan Teknik Industri UKM.; "Kumpulan Teori dan Diktat Kuliah APK \& E II", Laboratorium APK \& E Fakultas Teknik Jurusan Teknik Industri UKM, Bandung, 2008.

Ulrich, Karl T. dan Eppinger, Steven D.; "Perancangan dan Pengembangan Produk”, Salemba Teknika, Jakarta, 2001.

Weimer, Jon.; "Handbook of Ergonomic and Human Factor Tables", PTR Prentice Hall.Inc, New Jersey, 1993.

Yudiantyo, Wawan. ST., MT.: “Diktat Kuliah, Kesehatan dan Keselamatan Kerja”, Bandung. 